\title{
Resource Constraints and the Criminal Justice System: Evidence from Judicial Vacancies
}

\section{Citation}

Crystal S. Yang, Resource Constraints and the Criminal Justice System: Evidence from Judicial Vacancies (Harvard John M. Olin Discussion Paper Series Discussion Paper No. 820, Apr. 2015).

\section{Published Version}

http://www.law.harvard.edu/programs/olin_center/papers/pdf/Yang_821.pdf

\section{Permanent link}

http://nrs.harvard.edu/urn-3:HUL.InstRepos:17915541

\section{Terms of Use}

This article was downloaded from Harvard University's DASH repository, and is made available under the terms and conditions applicable to Other Posted Material, as set forth at http:// nrs.harvard.edu/urn-3:HUL.InstRepos:dash.current.terms-of-use\#LAA

\section{Share Your Story}

The Harvard community has made this article openly available.

Please share how this access benefits you. Submit a story.

Accessibility 


\section{HARVARD}

JOHN M. OLIN CENTER FOR LAW, ECONOMICS, AND BUSINESS

RESOURCE CONSTRAINTS AND THE CRIMINAL JUSTICE SYSTEM: EVIDENCE FROM JUDICIAL VACANCIES

Crystal S. Yang

Discussion Paper No. 820

$04 / 2015$

Harvard Law School

Cambridge, MA 02138

This paper can be downloaded without charge from:

The Harvard John M. Olin Discussion Paper Series:

http://www.law.harvard.edu/programs/olin_center/

The Social Science Research Network Electronic Paper Collection:

$\underline{\text { http://ssrn.com/abstract=2594019 }}$ 


\title{
RESOURCE CONSTRAINTS AND THE CRIMINAL JUSTICE SYSTEM: EVIDENCE FROM JUDICIAL VACANCIES
}

\author{
Crystal S. Yang*
}

This Version: March 2015

\begin{abstract}
Ten percent of federal judgeships are currently vacant, yet little is known on the impact of these vacancies on criminal justice outcomes. Using judge deaths and pension eligibility as instruments for judicial vacancies, I find that prosecutors decline more cases during vacancies. Prosecuted defendants are more likely to plead guilty and less likely to be incarcerated, suggesting more favorable plea deals. The incarceration effects are larger among defendants represented by private counsel. These estimates imply that the current rate of vacancies has resulted in 1000 fewer prison inmates annually compared to a fully staffed court system, a 1.6 percent decrease.
\end{abstract}

JEL Classifications: D70, H11, K14, K40

*Assistant Professor of Law, Harvard Law School. I am very grateful to Alma Cohen, Will Dobbie, Henry Farber, Louis Kaplow, Larry Katz, Anup Malani, Thomas Miles, Edward Morrison, John Rappaport, Ryan Sakoda, Steve Shavell, Holger Spamann, Kathy Spier, Sonja Starr, and seminar participants at the American Law and Economics Association Annual Meeting, University of Chicago, University of Toronto, Georgetown, and Harvard for helpful comments and suggestions. All errors are my own. E-mail: cyang@law.harvard.edu. 


\section{Introduction}

In recent years, the U.S. legal system has operated under substantial resource constraints. Nationwide, courts, prosecutors', and public defenders' offices have faced severe budget cuts, with hundreds of millions of dollars in criminal justice funding cut in the recent financial downturn. In particular, extended judicial vacancies have become an increasingly salient feature of the legal system, with at least 26 states delaying the filling of open judgeships (American Bar Association 2011).

Vacancies also plague the federal courts, with over ten percent of authorized judgeships currently unfilled. Some judgeships have been vacant for over seven years and over 40 percent of vacancies are classified as judicial emergencies because they arise in some of the busiest courts. Between 1999 and 2010, all but three of the 94 district courts faced at least one judicial vacancy and over one third of all federal suspects were prosecuted during vacancies in the relevant district court. By 2010, a quarter of all district courts had over 20 percent of their judgeships unfilled. As a result, the federal court system is currently operating under the longest period of historically high vacancy rates in 35 years (Rutkus and Smelcer 2011), leading to "overburdened courts, mounting caseloads, [and] the breakdown of the administration of justice" (Ashcroft 2003).

These judicial vacancies have potentially enormous consequences for the criminal justice system. Vacancies may increase the time it takes to prosecute defendants, yielding substantial delays in the resolution of cases and the administration of justice (Bannon 2014). On the other hand, judges and other actors, such as prosecutors, may find ways to resolve cases more efficiently given the resource constraints.

Yet, despite the judicial vacancy crisis, no empirical work to date has analyzed the extent to which these vacancies affect criminal justice outcomes. Empirically estimating the impact of resources on criminal justice outcomes has been complicated by two important issues. First, there is little information on the outcomes of defendants through each stage of the criminal justice process. Datasets often do no not permit reliable tracking of individuals across stages such as arrest and charging, making estimates prone to selection bias. Second, measuring the impact of resource constraints on outcomes falls prey to endogeneity problems, as many measures of resource constraints, such as caseload pressures, may be endogenous to prosecutorial practices 1

This paper confronts both of these issues. I construct a rich dataset that tracks offenders from arrest, to charging, to sentencing in order to estimate the impact of resource constraints on criminal justice outcomes, largely determined by the discretionary actions of prosecutors. The data overcome selection issues and allow for an examination of prosecutorial decision-making at every

\footnotetext{
1“"The overall tenacity of our prosecutors' is one key reason for the big criminal caseload."

See http://www.buffalonews.com/city-region/federal-court/arcara-move-creates-second-opening-on-delay-plaguedfederal-court-20140725.
} 
stage of the criminal justice process: the decision to prosecute, the decision to dismiss, charging, plea bargaining, and sentencing.

As a plausibly exogenous measure of resource constraints, I exploit variation in the timing and length of all 433 federal judicial vacancies from 1999-2010, which significantly increased the caseloads of remaining judges. Collecting information on the beginning of each vacancy when an incumbent leaves to the end when a successor is confirmed, I construct vacancy spells in each district court. Because numerous vacancies arise in the same district court, the number of vacancies in any month-year ranges from zero to up to seven, providing significant variation across court and time. These frequent and lengthy vacancy spells allow me to estimate the impact of resource constraints by comparing the outcomes of cases decided during vacancies to periods with no vacancies.

However, estimates may be biased if judges' decisions to vacate their seats is correlated with unobservables that also affect criminal justice outcomes. For instance, judges may elect to vacate their seats when prosecutors pursue a large number of cases, or certain types of cases. To address potential endogeneity in the timing of vacancies, I use two instruments for the number of actual vacancies. First, I analyze outcomes during vacancies caused by judge deaths, an exogenous shock to a court. Second, I exploit variation stemming from the federal judicial pension eligibility rule, a factor of judge age and tenure, which is highly predictive of a judge's decision to vacate his or her seat.

Ordinary least squares and two-stage least squares estimates indicate that greater scarcity in judges induces prosecutors to allocate scarce resources by using screening mechanisms. Using the current ten percent vacancy rate as a benchmark, I find that prosecutors are 0.12 to 0.84 percentage points more likely to decline to prosecute a case after arrest, a four to 27 percent increase from the mean rate. Even after filing charges, prosecutors are 0.15 to 0.63 percentage points more likely to dismiss a case in a ten percent vacant court, a three to 14 percent increase from the mean. Dropped cases do not appear to be deferred to state or local prosecutors.

Next, I explore the outcomes of cases adjudicated during periods of judicial vacancy. I find that prosecuted defendants are more likely to plead guilty and more likely to receive non-incarcerative sentences versus imprisonment during periods of vacancies. A ten percent vacant court increases the rate of guilty pleas by 0.15 to 0.29 percentage points and reduces the incarceration rate by 0.29 to 0.67 percentage points. While these estimates are small in magnitude given that over 90 percent of defendants plead guilty and over 84 percent are incarcerated, the results are economically important. The magnitudes are between 20 to over 50 percent the impact of being a black defendant compared to being a white defendant, a parameter of key interest.

The combined results are consistent with a story in which judicial vacancies increase prosecution and trial costs. Prosecutors respond to judicial scarcity by screening out cases, potentially 
marginal cases with weaker or more contestable evidence. When cases are prosecuted during judicial scarcity, prosecutors appear to offer more favorable plea deals in order to obtain guilty pleas and avoid going to trial. As a result, I find no significant increase in case delays or resolution times during periods of judicial vacancies.

Whether the impact of judicial vacancies on criminal justice outcomes is desirable depends on the social costs and benefits of increased dismissals and more favorable plea offers. If prosecutors are unable to devote resources to investigating cases or forced to dismiss viable cases in the face of resource constraints, the deterrent and incapacitative effects of criminal sanctions may be reduced. However, the presence of resource constraints may also force prosecutors to more effectively screen out cases of innocent defendants and people who are not deserving of conviction and incarceration. Specifically, I find that case declinations and more favorable plea offers stem largely from drug offenses.

Even if the reduction in incarceration and prison years is desirable, judicial vacancies have distributional consequences. I find that judicial vacancies do not affect all defendants equally, differing in particular by defense counsel. Lower rates of incarceration and shorter prison sentences during vacancies accrue to defendants who are able to retain private counsel, compared to indigent defendants, exacerbating inequities due to defense counsel type.

This paper fits within an earlier literature on prosecutorial charging and plea bargaining, beginning with seminal works both descriptive (Alschuler 1968, Scott and Stuntz 1992, Schulhofer 1984) and theoretical (Landes 1971, Easterbrook 1983, Grossman and Katz 1983, Reinganum 1988), and a smaller literature on the decision to prosecute (Cole 1970, Frase 1980, Wright and Miller 2002). The paper also connects to an empirical literature documenting the effect of caseload pressures on sentencing outcomes (Nardulli 1979, Ulmer and Johnson 2004), and management tactics by trial judges in the face of caseload pressure (Beenstock and Haitovsky 2004, Robel 1990). In the civil context, researchers have found that judicial vacancies are uncorrelated with litigation delay in the federal courts (Dayton 1993), and that federal circuit courts flooded with cases are less likely to overrule district court decisions compared to the other circuits (Huang 2011). Busier bankruptcy judges allow more firms to reorganize and liquidate fewer firms (Iverson 2014). Most broadly, the paper relates to a large literature on understanding the preferences and incentives of government officials, such as prosecutors (Boylan and Long 2005, Glaeser et al. 2000, Gordon and Huber 2002, Rasmusen et al. 2009, Rehavi and Starr 2014), judges (Gordon and Huber 2007, Lim 2013), and police (Mas 2006, Ater et al. 2014).

The remainder of the paper is structured as follows. Section 2 provides a brief overview of prosecutors and judicial vacancies. Section 3 presents a conceptual framework. Section 4 describes the data and provides summary statistics. Section 5 describes the empirical methodology and Section 6 presents results. Section 7 concludes. 


\section{Federal Prosecutors and Judicial Vacancies}

\subsection{Prosecutorial Discretion}

At the forefront of the federal criminal justice system are the United States Attorneys who are in charge of bringing criminal prosecutions. A total of 93 U.S. Attorneys serve under the direction of the Attorney General and are appointed by the President, with the advice and consent of the Senate. Each U.S. Attorney supervises numerous Assistant U.S. Attorneys (AUSAs) within his or her jurisdiction.

These AUSAs possess enormous discretion in enforcing the nation's criminal law. Prosecutors control charging and plea bargaining decisions, and ultimately sentence lengths as over 95 percent of federal offenses are resolved through guilty pleas. Prosecutorial bargaining power is only enhanced by the existence of severe mandatory minimum statutes, and until recently, limited judicial discretion under the Federal Sentencing Guidelines. ${ }^{2}$

Following arrest, criminal division AUSAs, approximately 90 percent of all AUSAs, assist federal law enforcement agencies in the investigation and prosecution of offenders who have violated federal criminal laws within the relevant district. Once a law enforcement agency makes an arrest, an agent presents the AUSAs with evidence that would warrant filing formal charges. If a prosecutor decides that there is insufficient evidence to prosecute, the AUSA issues a declination and the case is closed (Frase 1980, Miller 1969). Other reasons for declination include policy rationales and referrals for state prosecution. The decision not to prosecute, and the analogous decision to dismiss a prosecution later on, are highly discretionary. In fact, private parties do not have standing to compel prosecution.

Under the United States Attorneys' Manual, “an attorney for the government should initiate or recommend Federal prosecution if he/she believes that the person's conduct constitutes a Federal offense and that the admissible evidence probably will be sufficient to obtain and sustain a conviction." In making such a determination, the federal prosecutor can consider factors such as whether the prosecution would serve a substantial federal interest, whether the alleged offender is subject to effective prosecution in another jurisdiction, and whether there are adequate and viable noncriminal alternatives to prosecution. However, Department of Justice policy states that prosecution based on a suspect's race, religion, sex, national origin, or political association, is impermissible.

To formally bring charges, a prosecutor must generally obtain an indictment from the grand jury. If the defendant waives indictment by a grand jury, the prosecutor may proceed via information. In general, prosecutors have control over the selection of initial charges. Following the filing of charges, most cases are resolved through plea bargaining. During plea negotiations, the

\footnotetext{
${ }^{2}$ Under the Sentencing Reform Act of 1984, Congress adopted the Federal Sentencing Guidelines to eliminate disparity in punishment, reducing judicial discretion, and shifting power to prosecutors.
} 
prosecutor and defense attorney are likely to discuss the merits of the case, and whether there are mitigating factors that justify the imposition of a more lenient sentence. Some argue that plea negotiations are less based on evidentiary merits, but rather by the prosecutor overcharging as a bargaining chip, and setting a higher than warranted sentence in order to reach a compromise.

In the background of these decisions are limited resources. Judicial vacancies, or resource constraints more generally, may impact the number of cases that can be prosecuted and tried. When there are fewer judges available, prosecutors may incur costs from prosecuting a case regardless of whether the defendant ultimately goes to trial. For instance, the Speedy Trial Act of 1974 establishes time limits for completing various stages of a federal criminal prosecution. The Act requires the government to file an indictment within 30 days of a defendant's arrest. If a defendant enters a plea of not guilty, he or she must be tried within 70 days of the indictment, which can be extended if a judge grants a continuance. The tolling of the speedy trial clock also stops when there is a pre-trial motion pending, during which a judge has 30 days to decide on the motion. Generally, if these motions are decided unfavorably to the defendant, the defendant ends up pleading guilty prior to trial commencing.

Because speedy trial violations have potentially severe consequences, prosecutors face higher costs of prosecution when there are vacancies that increase the workloads for remaining judges. If a defendant is not indicted on time, charges must be dropped. If a defendant is not tried on time, he or she may move to dismiss the charges, with the court having discretion to dismiss with prejudice, which would bar a subsequent prosecution. In fact, charges can be dismissed with prejudice even if the speedy trial violation results from a judge failing to rule on a motion within the specified time period with no fault attributable to the prosecutor, requiring prosecutors to be especially alert to the speedy trial clock and to monitor the court's compliance $]^{3}$ Even if there is no speedy trial violation, prosecutors may also face costs from delay in the resolution of a prosecution and evidence becoming stale.

Prosecutors' trial costs, conditional on prosecution, also increase when there are judicial vacancies because a speedy trial violation can result in the government's case being dismissed. Indeed, recent media attention has highlighted criticisms of prosecutors who review every case and push to trial, despite mounting caseloads. Judges in these local courts have responded by allowing only one continuance per case in order to incentivize prosecutors to more effectively screen cases and strike plea deals prior to trial $4^{4}$

Recognizing that judicial vacancies affect their ability to prosecute cases, the National Association of Assistant United States Attorneys recently stated that "[o]ur members - career federal

${ }^{3}$ See United States v. Ramirez, 973 F.2d 36, 39 (1st Cir. 1992).

${ }^{4}$ See

http://www.yakimaherald.com/news/latestlocalnews/1591320-14/yakima-county-prosecutors-office-cutting-caseload-and-saving 
prosecutors who daily appear in federal courts across the nation - are concerned by the increasing numbers of vacancies on the federal bench. These vacancies increasingly are contributing to greater caseloads and workload burdens upon the remaining federal judges. Our federal courts cannot function effectively when judicial vacancies restrain the ability to render swift and sure justice."

Accordingly, judicial vacancies require prosecutors to allocate limited resources among potential cases, such that the number of active judges in a district court is effectively a bottleneck on prosecution $\sqrt[5]{5}$ Then United States Attorney for the Southern District of California, William Braniff, argued that high caseloads per judge, due to judicial vacancies, dramatically affected case processing, either through declination of certain cases altogether or conversion of cases from felonies to misdemeanors that can be adjudicated before magistrate judges (Braniff 1993). According to Braniff, prosecutors have the "discretion necessary to ensure that the criminal justice system does not become overwhelmed by local conditions" by balancing resources and crime, the "resource in shortest supply [being] the number of district judges."

Indeed, prosecutorial priorities and tradeoffs may be most revealing when resource constraints are acute because "[f]ederal law enforcement resources and federal judicial resources are not sufficient to permit prosecution of every alleged offense over which Federal jurisdiction exists" (United States Attorneys' Manual 2013). Thus, understanding how prosecutors adapt to resource scarcity in the federal courts also helps shed light on prosecutorial incentives and tradeoffs more broadly.

Theoretical work argues that prosecutors may selectively bring cases to court if bringing all viable cases would overwhelm the court system (Alschuler 1968, Landes 1971, Easterbrook 1983, Stuntz 2004). Qualitative evidence reveals that when caseloads reach an "overload point," prosectors become more selective in deciding which cases to prosecute (Cole 1970), resulting in greater dismissal of cases, but more favorable plea deals among remaining defendants that are prosecuted (Stemen and Frederick 2013). Simulations of plea bargaining in North Carolina suggest that an increase in trial costs for prosecutors would lead to a greater conviction rate, but reduction in total prison time due to more favorable plea offers (da Silveira 2012).

\subsection{Judicial Vacancies}

Concern over judicial vacancies is not new (Wheeler and Binder 2011). As of August 2013, ten percent of the authorized judgeships among the federal district and appellate courts were vacant, leading to the longest period of high vacancy rates in the last 35 years (Rutkus and Smelcer 2011), with over 40 percent of the vacancies designated as judicial emergencies.

\footnotetext{
5 "It makes no sense to have more people arresting and prosecuting criminals, including drug smugglers, if there aren't enough judges to try their cases."

See http://articles.sun-sentinel.com/1990-03-05/news/9001270731_1_federal-courts-federal-judges-new-appellate-judges
} 
Ideological differences between the appointing president and senators likely explain a large fraction of the increasing length of vacancies, with an average vacancy in the 1920s filled within four months, compared to over 20 months by the 2000s. In September 2013, the Senate Judiciary Committee's Subcommittee on Bankruptcy and Courts conducted a hearing on Senate Bill 1385, or the Federal Judgeship Act of 2013, which would create 91 new judgeships across two circuit courts and 32 district courts, directed at those courts with the most acute staffing needs.

Vacancies result from a variety of reasons: resignation, retirement, death, disability, and most commonly, the taking of senior status, an option created by Congress in 1919 in order to provide judges with an alternative between remaining active and retiring. Today, an active judge who reaches age 65 and has served for at least ten years is eligible for a pension if the sum of his age and years of service equal 80 , known as the Rule of 80 .

Senior judges occupy a unique position because a senior status vacancy may not result in increased caseload pressures. Although a senior judge remains on the bench, his elective status is treated as a vacancy that allows the president and Senate to appoint and confirm a full-time successor. Often, senior judges continue to hear cases, although they can select the number and types of cases they hear. Senior district judges on average carry a caseload that represents 63 percent of an active caseload, with almost a quarter of senior district court judges hearing a full caseload (Yoon 2005). As a result, a judge electing senior status may actually lead to a decrease in caseload per judge once a successor is confirmed.

Early work by scholars offered qualitative accounts of why judges leave the bench (Schmidhauser 1962, Fairman 1938), with later empirical evidence showing that a judge's decision to vacate is associated with political affiliation of the president and Senate majority (Barrow and Zuk 1990, de Figueiredo et al. 2000). Decisions to leave the bench are also correlated with pension qualification (Spriggs and Wahlbeck 1995, Choi et al. 2011), with some finding that judicial pensions are the dominant reason for vacancies (Yoon 2005, Yoon 2006), rather than political factors, or dissatisfaction with the Federal Sentencing Guidelines (Boylan 2004).

Because judicial retirement is primarily motivated by pension qualification, judicial vacancies caused by retirement or the taking of senior status are plausibly exogenous to underlying caseload pressures. In contrast, the decision of how many cases to hear for judges who take senior status is less likely exogenous to underlying workloads. Indeed, some recent judges who have taken senior status continue to carry a full caseload in order to aid their active colleagues (Bannon 2014).

The type of vacancy may also have different implications for the resulting confirmation process of a successor. If a judge's decision to retire, resign or take senior status is anticipated once the judge qualifies for his pension, the nomination and Senate confirmation process can precede the vacancy, although the confirmation process of successors is not affected by whether eligible incumbent judges take senior status or retire (Yoon 2005). In contrast, a vacancy created by a 
judge's death is exogenous and may result in a lengthier confirmation process.

\section{Conceptual Framework}

This section presents a simple one-sided asymmetric information model of charging and plea bargaining to illustrate the effects of judicial vacancies on criminal justice outcomes, adapted from Bebchuk (1984). The model allows for screening through selective prosecution such that the set of cases that are prosecuted is a non-random sample of arrestees. Given individualized plea offers, the set of cases that reach trial is also non-random. To conserve space, I summarize the main insights of the model here. Additional details are presented in Appendix B.

In the model, the prosecutor seeks to maximize the sanctions imposed and the defendant seeks to minimize the sentence imposed. The model proceeds in three stages. First, the prosecutor unilaterally decides whether to prosecute from a pool of arrested suspects, where the prosecutor observes an exogenous signal of the strength of the case, which is common knowledge. The defendant has private information over his own culpability. If the prosecutor decides to proceed, he expends a cost of prosecution. In the second stage, the prosecutor and defendant bargain over the sentence, where the prosecutor makes a take-it-or-leave-it plea offer. If the defendant rejects the plea, the parties go to trial in the third stage, during which both parties expend additional trial costs. The probability of conviction at trial is increasing in both the strength of the case and the defendant's culpability. See Appendix Figure 1 for a game tree diagram. The perfect Bayesian equilibrium gives rise to a defendant's decision rule, the optimal plea offer, and the prosecutor's decision rule of which defendants to prosecute.

An increase in resource constraints in the form of judicial vacancies can be thought of as an increase in (1) the cost of prosecution and (2) an increase in the cost of going to trial, conditional on prosecution. Costs of prosecution (regardless of plea or trial) increase because vacancies may delay the resolution of cases, potentially resulting in speedy trial violations, and can lead to evidence becoming stale. Prosecutors may also face reputational costs within the local court by burdening judges with high caseloads during periods of vacancies. Trial costs, conditional on prosecution, also increase because of speedy trial issues, as well as the loss of witnesses and evidence if there are delays in going to trial.

Under these assumptions, the model suggests that vacancies result in two main effects. First, prosecutors will only pursue those cases with higher expected sanctions, dropping cases with weaker or more contestable evidence. If this selection effect dominates, the average plea offer is less favorable to the defendant, and the average probability of pleading guilty is lower. However, conditional on being prosecuted, prosecutors will offer more favorable plea deals to avoid going to trial. If this effect dominates, the average plea offer is more favorable to the defendant, and the 
probability of pleading guilty is higher in equilibrium.

\section{Data}

To estimate the impact of judicial vacancies on the criminal justice system, I use data from two primary sources: (1) the Administrative Office of the United States Courts (AOUSC), and (2) the Department of Justice's Bureau of Justice Statistics (BJS).

AOUSC Data: Data on all unfilled district court vacancies from 1999-2010 are collected from the AOUSC ${ }^{6}$ I collect information on the date of each judicial vacancy, date of nomination and confirmation of a successor, and the reason for the vacancy. During the time period 1999-2010, there were a total of 433 unfilled district court vacancies (See Table 1). 7

Eighty percent of the vacancies are created by judges who elect senior status. As mentioned previously, senior judges remain on the bench, although their elective status is treated as a vacancy that allows the president to appoint a full-time successor. Because senior status judges continue to hear cases, the impact of a vacancy resulting from senior status may be less on average than that due to other reasons such as death, elevation, and resignation. Moreover, a judge electing senior status may actually lead to a decrease in caseload per judge, or increase in judicial capacity, once a successor is confirmed.

Approximately five percent of vacancies are created by judge deaths, and another eight percent due to resignation or retirement. During the time period, ten judges left their judgeships for disability reasons and two judges left to be director of the Federal Judicial Center. Thirty-two new judgeships were authorized by Congress, expanding the size of the court. Thirty-eight percent of the vacancies were classified as judicial emergencies. The number of total vacancies affecting any district court at any point in time ranges from zero to up to seven vacancies during the time period.

Table 2 presents summary statistics on the average delays in the vacancy to confirmation process. Among these 433 vacancies, the average delay from vacancy to nomination of a successor is 1.2 years or 14 months. The average delay from vacancy to Senate confirmation is 1.6 years or 19 months. Even within the twelve year period from 1999 to 2010, nomination and confirmation delays have increased by approximately .3 years or four months. Note that sometimes nomination and confirmation can occur before the scheduled vacancy. Almost all instances of confirmation preceding vacancies are attributed to judges who take senior status, who likely announce their intentions to take senior status well in advance of vacating their seats.

BJS Data: Data on arrests and charges are obtained from several datasets collected by the BJS from fiscal years 1999-2010. The BJS collects data on all arrests and bookings for federal offenses

\footnotetext{
${ }^{6}$ Vacancies unfilled from 1999-2010 begin from 1994-2010.

${ }^{7} \mathrm{~A}$ breakdown of vacancies by district court is presented in Appendix Table A1.
} 
in each fiscal year from the United States Marshals Service Prisoner Tracking System database. Records include arrests made by federal law enforcement agencies and state and local agencies. These data on all arrests and bookings are linked to records of all suspects of federal criminal matters concluded by United States attorneys or magistrate judges, obtained from the Executive Office for United States Attorneys $\square^{8}$ For each defendant, I observe the arrest month-year, filing month-year (if available), disposition month-year (if available), and termination month-year (if available). All cases are terminated as of the end of fiscal year 2010. For the sample of arrestees linked to suspects concluded, I restrict the analysis sample to those with valid disposition dates (month and year), dropping observations with missing disposition dates (approximately 25\%) or those with invalid dates.9

To obtain more detailed charging information and sentencing outcomes of arrestees who are prosecuted in district court, I link the arrest data to charging and sentencing data provided by the AOUSC for all defendants filed and terminated in district court. Linking of records across datasets is done pursuant to paired agency link files provided by the BJS, which allow individual defendants to be tracked through each stage of the federal criminal justice program, from arrest to prosecution, adjudication, sentencing and corrections 10 For the sample of arrestees linked to suspects concluded, further linked to defendants filed and terminated in district court, I restrict the analysis sample to those with valid filing and termination dates, dropping approximately $1 \%$ of the sample.

This linked dataset provides defendant demographic information including race, gender, age, and citizenship status (provided in the arrest files). Offense characteristics include a highly detailed arrest offense provided by the United States Marshals Service, type of charge, the lead criminal charge, number of total counts, offense date, as well as whether the case was heard before a district court judge or magistrate judge. Data are also provided on the disposition of the arrest, such as whether the defendant was ultimately convicted, found guilty through plea, or whether charges were dismissed or prosecution declined. Disposition of a case arises either from declination, the defendant being acquitted, or a guilty adjudication through plea bargaining or trial. A declined or acquitted defendant is terminated the same day as being disposed, but a guilty defendant is terminated when sentenced.

Data from the AOUSC also contain offense codes for up to five offenses charged at the time the case was filed, with a "most serious" offense charge determined based on the highest statutory maximums associated with each charge. The AOUSC data also track the most serious charge at

\footnotetext{
${ }^{8}$ Data on suspects concluded does not contain information on suspect demographics or district court.

${ }^{9}$ In unreported results, I find that the probability of a case missing a disposition date is uncorrelated with vacancies at the time of arrest or filing. Invalid dates are those where the disposition or termination date is recorded as having occurred prior to arrest or filing of charges, approximately $1 \%$ of the sample.

${ }^{10}$ Descriptions of the data and linking files can be found at http://www.icpsr.umich.edu/icpsrweb/content/NACJD/guides/fjsp.html.
} 
filing and most serious charge at termination, which may differ due to plea bargaining, or the judge or jury at trial.

Summary statistics on arrestees linked to suspects concluded are presented in Panel A of Table 3. Sixteen percent of arrested suspects are black, and 81 percent are white. Over 86 percent of suspects are male and less than half are U.S. citizens. The average suspect is 32 years of age, arrested for the three most common crime categories of immigration, drugs and property offenses. 3.1 percent of cases are declined, and 1.8 percent are removed or transferred to another court. Over 30 percent of criminal prosecutions are resolved by a magistrate judge.

Conditional on filing charges in district court (Panel B), charges are eventually dismissed in five percent of cases. 95 percent of suspects are found guilty, with 92 percent pleading guilty. 84 percent of defendants are incarcerated. Defendants serve an average sentence of 45 months in prison.

Table 3 also presents summary statistics on the average delay, in years, from the beginning of the criminal justice process at arrest, to filing, and disposition. The average delay from arrest to disposition, whether due to declination, dismissal, or guilty adjudication is 0.35 years or 4.2 months. Of cases in which charges are filed in district court, the average delay from filing to case disposition is 0.42 years or five months.

Judicial vacancies are also quite frequent during this time period. All but three of the 94 district courts have at least one judicial vacancy. Of all suspects arrested during this period, almost 40 percent of suspects are declined, dismissed, or prosecuted during a time characterized by at least one judicial vacancy in the relevant district court. Figure 1 graphs the number of vacancies in each month over the time period 1999-2010.

Note that those suspects that can be linked from the arrest to prosecutorial filing stage, approximately 50 percent of all suspects, may be unrepresentative of all suspects investigated in federal courts. Indeed, there are some notable differences when one looks at case disposition outcomes for the universe of suspects of federal criminal matters concluded during the same time period (see Panel C of Table 3) compared to outcomes for arrestees linked to suspects (Panel A) and defendants prosecuted in district court (Panel B). Whereas only three percent of linked suspects are declined for prosecution, 27 percent of all suspects are declined for prosecution, suggesting that declined arrestees are less likely to be matched across datasets. However, rates of transfers, dismissals and pleas (conditional on filing charges in district court) are similar across datasets. As a result, estimates in this paper using the linked arrest to suspects concluded dataset may be an underestimate of the true magnitude of the impact of a shortage of judges on declination. 


\section{Empirical Methodology}

This paper exploits the timing and length of judicial vacancies to estimate the effect of resource constraints on criminal justice outcomes. The empirical methodology compares outcomes of suspects processed by prosecutors during periods of judicial vacancy compared to periods with no vacancy. See Figure 2 for a graphical depiction of how prosecution and charging might fall between a vacancy and confirmation.

I begin by presenting ordinary least squares estimates from the following specification:

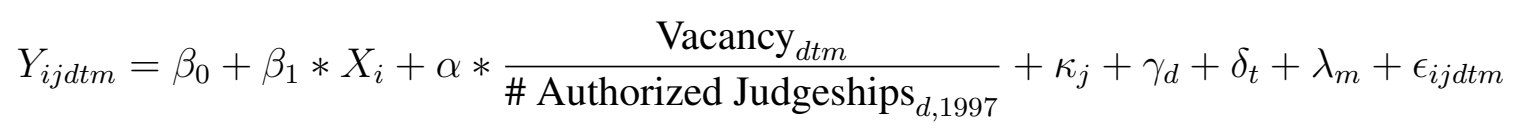

where $Y_{i j d t m}$ is a case outcome for suspect $i$ arrested for offense $j$, whose case is determined in district court $d$, in year $t$ and month $m$.

Case outcomes include prosecution delay, whether the case was declined or dismissed, whether the suspect pleads guilty, and whether the suspect is found guilty. Charging and sentencing outcomes include the type of charge, the number of charge counts, whether the defendant is incarcerated, and the length of imprisonment imposed at sentencing.

$\mathbf{X}_{i}$ comprises a vector of demographic characteristics of the defendant including gender, age, age squared, race, and citizenship status. $\kappa_{j}$ are fixed effects for 399 detailed arrest offense categories. Importantly, the arrest offense is determined by the United States Marshals Service, rather than the prosecutor, resulting in a plausibly exogenous measure of actual offense severity.

The specification also includes district court fixed effects $\left(\gamma_{d}\right)$, disposition year fixed effects $\left(\delta_{t}\right)$, and disposition month fixed effects $\left(\lambda_{m}\right)$. All standard errors are clustered at the district court level to account for serial correlation.

Vacancy $_{d t m}$ equals the number of judicial vacancies for arrested suspects whose cases are decided in a month-year, and ranges from zero to seven during the time period. ${ }^{11}$ For outcomes that are decided at the time a case is disposed, (declination, dismissal, deferral for state prosecution, transfer), I define Vacancy Vtm $_{\text {a }}$ as the number of vacancies in the month-year that the arrestee's case was disposed of.

For all other outcomes that arise anytime between filing charges in district court and disposition of the case, I define Vacancy ${ }_{d t m}$ as the number of vacancies in the month-year of filing that persist through disposition of the case. Intuitively, a defendant is treated as having been prosecuted during judicial scarcity if at least one vacancy was present the entire time from filing to disposition. I define vacancies in this manner because many of the outcomes, such as a plea, can occur at any point between filing and disposition and the data do not identify the exact time of each decision.

\footnotetext{
${ }^{11}$ I exclude vacancies that are created by a new judgeship, since these do not actually increase caseload pressures.
} 
Approximately $11 \%$ of defendants face at least one vacancy at filing, but no vacancies at disposition, and vice versa. I deal with these partial vacancies by controlling for the number of vacancies at filing to eliminate the endogeneity between the length of time from filing to disposition and vacancy persistence, as well as unobservables about each case. For instance, cases that take longer may be more complicated.

However, the total number of judicial vacancies does not have the same effect across all district courts. The average district court has nine authorized judgeships, but some district courts have over 20 authorized judgeships. As a result, I control for the fraction of the court that is vacant, with the total number of authorized judgeships in each district court indexed to 1997 values $\frac{\text { Vacancy }_{d t m}}{\text { \# Authorized Judgeships }}{ }_{d, 1997}$. During the time period, the fraction of the court vacant ranged from zero to one, with a standard deviation of 0.09 . Under this specification, $\alpha$ captures the impact of the fraction of the courthouse vacant on case outcomes.

If the timing of judicial vacancies is uncorrelated with unobservables that affect prosecutorial decisions, the specification provides a causal estimate of the impact of a shortage in judges on criminal justice outcomes.

\subsection{Potential Endogeneity and the Use of Instrumental Variables}

However, a threat to identification arises if the decision to vacate a seat is affected by unobservable resource constraints or work pressures, which may be correlated with prosecutorial charging decisions. For instance, a judge may elect to vacate his or her seat in response to unobservable shocks to a district court, creating a vacancy that could bias the estimates. To address potential endogeneity concerns attributable to the strategic timing of vacancies, I use two instrumental variables.

First, I separately estimate specification (1) using only those vacancies created by judge deaths, an exogenous shock to a court's judicial capacity. Because a vacancy spell arising from death starts on the date that a judge dies, ordinary least squares estimates are identical to two-stage least squares estimates in this subsample.

Second, I instrument for the timing of senior status vacancies, $80 \%$ of the vacancies in the sample, using pension eligibility rules. Recall that a judge who is at least age 65 and has served for at least ten years is eligible for a pension if the sum of his age and years of service equal 80. According to the AOUSC, slightly more than half of all federal judges take senior status within just one month after becoming eligible, and 75 percent take senior status within a year of qualifying for their pensions. 12

\footnotetext{
${ }^{12}$ Prior research (Yoon 2006) finds that the timing of senior status is almost exclusively correlated with pension eligibility, which is a factor of judge tenure and age, rather than gender, race, court characteristics, as well as political factors like party of the president, party of the judge, majority control of the Senate.
} 
Using the Rule of 80, I compute the month-year that a judge becomes pension eligible using each judge's birthdate and commission date, collected from the Federal Judicial Center. ${ }^{13}$ For instance, a judge born in April 1940 who was commissioned to the federal bench in July 1990 would qualify for his or her pension in April 2005. Consistent with prior research, I find that of the 303 senior status vacancies, over $60 \%$ of judges take senior status in the year they become eligible, with another $15 \%$ taking senior status the following year. In contrast, vacancies caused by judge deaths and other reasons occur both before and after pension eligibility. See Figure 3.

I then construct predicted vacancy spells using the start date of the spell as the month-year that a judge becomes pension eligible, rather than the month-year that the judge actually declares his or her vacancy. Using these predicted vacancy spells, I calculate a predicted number of senior status vacancies in each month-year, $Z_{d t m}$, which I use as an instrumental variable for the actual number of senior status vacancies each month-year, $\mathrm{V}_{d t m}$.

I estimate a second-stage equation of the form:

$$
Y_{i j d t m}=\beta_{0}+\beta_{1} * X_{i}+\alpha * \widehat{\mathrm{V}_{d t m}}+\kappa_{j}+\gamma_{d}+\delta_{t}+\lambda_{m}+\epsilon_{i j d t m}
$$

with corresponding first stage equation:

$$
\mathrm{V}_{d t m}=\pi_{0}+\pi_{1} * X_{i}+\pi_{2} * \mathrm{Z}_{d t m}+\kappa_{j}+\gamma_{d}+\delta_{t}+\lambda_{m}+\epsilon_{i j d t m}
$$

Appendix Table A2 presents the first-stage regressing the actual number of senior status vacancies on the predicted number, controlling for all offense and demographic characteristics, district court, year, and month fixed effects. Standard errors are clustered at the district level. Unsurprisingly, predicted vacancies calculated using pension eligibility month-year are highly predictive of the actual number of vacancies, with an F-statistic of 446, such that one predicted vacancy is associated with a 0.65 increase in actual vacancies.

A primary assumption underlying the empirical methodology is that there is no change in the arrest pool during periods of judicial vacancies. If local and federal police agencies respond to judicial vacancies, such as by declining to arrest, selection into the arrestee pool changes and estimates of changes in criminal justice outcomes are potentially biased. While there are no data on the pool of all potential arrestees, I can test whether judicial vacancies at the time of arrest are

\footnotetext{
${ }^{13}$ Birth month is only available for $20 \%$ of the judges while commission month is available for all judges, so monthyear variation comes largely from judges who qualified for the Rule of 80 after they turn 65 (approximately $50 \%$ of all judges), in which case commission month-year is determinative of pension eligibility month-year. For judges who qualify for their pension the exact year they turn 65, I define the pension eligibility month as January of the relevant year if birth month is not available.
} 
associated with changes in the number of total arrests, and the offense composition of those arrests.

Table 4 presents arrest patterns for all federal arrests and bookings from 1999-2010. In column 1 of Table 4, I analyze the total number of arrests per month-year in each district. In columns 2 through 6 , I explore changes in the composition of arrests, measured by the proportion of arrests that are drug crimes, property crimes, public order crimes, weapons crimes, and immigration crimes. I find no significant change in the number or composition of arrestees, with fairly precisely estimated zeros, suggesting that judicial vacancies do not prompt large changes in arresting behavior by either local or federal law enforcement agencies.

\section{Results - Impact of Judicial Vacancies on Criminal Justice Outcomes}

In this section, I present results on the impact of judicial vacancies on outcomes at multiple stages of the criminal justice process. A prosecutor terminates a case early by either declining to prosecute or dismissing the case. If a prosecutor decides to pursue the case, he or she has vast discretion in filing charges, and shaping the subsequent plea bargaining, trial and sentencing outcomes.

\subsection{Declinations and Dismissals During Vacancies}

I first present results for declinations, deferrals, and dismissals of cases concluded during at least one judicial vacancy, compared to cases disposed of during periods characterized by no judicial shortage. Column 1 of Table 5 presents the mean for each outcome. Column 2 presents ordinary least squares results on the full sample of judge vacancies. Column 2 presents results using only judge deaths. Column 3 presents ordinary least squares results for senior status vacancies, and column 4 provides two-stage least squares results instrumenting with the predicted number of senior status vacancies using pension eligibility. The total number of vacancies in any month-year due to death is one, compared to up to five for senior status vacancies. Each of the specifications controls for offense and demographic characteristics, as well as district court, disposition year, and disposition month fixed effects. Standard errors are clustered at the district court level throughout.

Column 2 indicates that among the full sample of vacancies, the current ten percent vacancy rate corresponds to a 0.12 percentage point increase in declinations, a four percent increase from the mean rate of 3.1 percentage points. How economically important are these magnitudes? In column 1 of Appendix Table A3, I present the coefficients of other demographic characteristics on the probability of declination. Cases involving male offenders are 1.2 percentage points more likely to be declined, compared to similar female arrestees. Similarly, U.S. citizens are 1.7 percentage points more likely to be declined for prosecution compared to non U.S. citizens. Declination rates 
do not differ significantly by offender race. These coefficients imply that the magnitude of the current ten percent vacant court system is ten percent that of the impact of being a male offender, and seven percent that of being the impact of a U.S. citizen.

Increased rates of declinations during vacancies appear to be predominately driven by judge deaths, with a ten percent vacant court increasing the probability of declination by 0.84 percentage points, a 27 percent increase from the mean, 70 percent of the impact of being a male offender and 50 percent the impact of being a U.S. citizen. In contrast, vacancies driven by senior status judges are not significantly associated with the rate of declination across either ordinary least squares or two-stage least squares specifications.

An increased rate of declinations does not necessarily imply that dropped defendants are never prosecuted. In fact, cases that are declined by federal prosecutors during periods of vacancies may be picked up by state or local prosecutors if there is concurrent jurisdiction over the case. However, I find no significant evidence across the four specifications that declinations during periods of judicial vacancies are subsequently prosecuted at the state or local level. Nevertheless, my estimates are unable to capture any decisions about federal versus state prosecution that are made prior to any arrest, such as when an investigation is pending. But if federal prosecutors referred cases for state prosecution prior to a federal arrest, one would expect the total number of arrests to decline during periods of judicial vacancies, not observed in Table 4.

Even after filing charges in district court, cases can be dismissed. Prosecutors may be more likely to dismiss a case once more information regarding the strength of the case is revealed after discovery. I next present results on the impact of judicial vacancies on the probability of dismissal conditional on filing charges, such that the case was not initially declined.

Generally, cases involving black defendants are 0.52 percentage points more likely to be dismissed compared to white defendants. Male defendants are 1.5 percentage points less likely to be dismissed than female defendants, conditional on filing charges (Appendix Table A3). Across the specifications, I find evidence that judicial vacancies are associated with increases in the probability of case dismissal. In the full sample, a ten percent vacancy rate corresponds with a 0.15 percentage point increase in dismissals, a three percent increase from the mean rate of 4.6 percentage points. This magnitude is 29 percent the impact of being a black offender compared to being a white offender.

Results are robust looking at judge deaths, with a ten percent vacant court increasing the probability of dismissal by 0.63 percentage points, a 14 percent increase from the mean. Increases in dismissals are also driven by senior status vacancies. A court with a ten percent vacancy is associated with a 0.15 percentage point increase in dismissals, a three percent increase from the mean. Two-stage least squares estimates of senior status vacancies are qualitatively similar, although the estimates lose statistical significance. 
Subsample results by broad offense categories are presented in Appendix Table A4 and reveal that declinations during vacancies are somewhat larger among drug offenses. Similarly, dismissals during vacancies are greater among drug and immigration offenses.

\subsection{Charging During Vacancies}

Table 6 presents results on various measures of charging of cases prosecuted during periods of judicial vacancy. First, I examine the likelihood that a case was filed before a magistrate judge, relative to a district court judge, during vacancies. A way in which prosecutors may ration scarcity of district court judges is to shift across institutional actors. In the federal criminal justice system, petty offenses and misdemeanors may be terminated by a magistrate judge.14 If district court judges become relatively more scarce compared to magistrate judges during periods of judicial vacancies, prosecutors may classify a greater number of offenses as misdemeanors or shift plea proceedings to magistrates ${ }_{15}^{15}$ However, I find no evidence that vacancies in the district court are associated with a higher likelihood of cases being filed in magistrate court.

Conditional on filing charges in district court, I next analyze the charging of defendants that are prosecuted in district court during periods of vacancy, which incorporate both a selection effect due to the changing composition of prosecutions, as well as direct treatment effect of judicial vacancies. I exclude declinations, dismissals, and cases opened by a transfer from another district. I present results for the likelihood that formal charges are filed via indictment (compared to information or complaint), which requires the use of a grand jury, the total number of charge counts, and the probability that the most serious initial charge is for a misdemeanor versus felony offense. Across all specifications, I find no evidence that vacancies are significantly associated with changes in the initial charging of cases, the starting point of plea negotiations.

\subsection{Plea Bargaining and Sentencing During Vacancies}

Next, I examine the impact of judicial vacancies on plea bargaining during prosecutions initiated during periods of judicial shortage. In Table 7, I assess the total rate of guilty adjudications, either from guilty pleas or guilty verdicts at trial. In general, black defendants are 0.29 percentage points less likely to be found guilty compared to similar white defendants.

Full sample ordinary least squares results indicate a significant effect of vacancies on the overall rate of guilty adjudications. The current ten percent vacancy rate corresponds to a 0.06 percentage point increase in guilty adjudications, a small increase from a baseline mean of 94.8 percentage

\footnotetext{
${ }^{14}$ Magistrate judge vacancies arise when the term appointment of eight years end.

${ }^{15}$ As noted by the Administrative Office of the U.S. Courts, "the federal courts have responded to the overall growth in caseload by using magistrate judges to meet the particular demands of their changing caseloads. For example, in recent years many courts have assigned an increasing number of felony guilty plea proceedings to magistrate judges."
} 
points. However, the effect is economically large, with the magnitude being 21 percent the impact of being a black defendant. Increases in the rate of guilty adjudications are driven largely by senior status vacancies, with two-stage least squares estimates suggesting that a ten percent vacant court is associated with 0.09 percentage point increase, 31 percent the impact of being a black offender.

I find compelling evidence that the higher rate of guilty adjudications during vacancies stems from a higher rate of guilty pleas, and conversely lower rate of trials. A ten percent vacant court is associated with a 0.15 percentage point increase in the rate of guilty pleas, whether using the full sample of vacancies or just those caused by senior status vacancies. Two-stage least squares results indicate that a ten percent vacant court is associated with a 0.29 percentage point increase in the rate of guilt pleas, 15 percent the impact of being a black offender, who is two percentage points less likely to plead guilty compared to similar white offenders. These results suggest that prosecutors may be able to avoid trial and obtain more guilty pleas when judicial capacity is reduced.

Given the increase in guilty pleas, I assess whether judicial vacancies affect certain types of plea bargains. Plea bargains generally come in two forms: charge bargains and sentence bargains. While the data do not distinguish between each type of plea bargain, I can examine whether the most serious offense at the time of filing differs from the most serious offense at the time of termination. Offense changes from filing to termination are the result of charge bargaining according to the AOUSC. Finally, I can also assess whether a charge for a felony offense at the time of filing is reduced to a charge for a misdemeanor offense at the time of termination. The results in Table 7 suggest that vacancies are not significantly associated with changes in charge bargaining or conversion of cases from felony offenses to misdemeanor offenses during periods of vacancy. However, vacancies created by judge deaths are associated with a decrease in the probability of a felony charge being converted to a misdemeanor charge at the time of disposition, which may capture the fact that prosecutors select stronger cases during periods of vacancies.

I next explore whether the greater rate of guilty pleas may be the result of more favorable pleas deals through sentence bargaining. In Table 8, I examine the impact of vacancies on plea deals by looking at sentencing outcomes of cases prosecuted during periods of vacancy compared to periods with full capacity. Table 8 reveals that judicial vacancies significantly reduce the likelihood of incarceration. A ten percent vacant court reduces the rate of incarceration by 0.29 percentage points, 12 percent the magnitude of being a black defendant, who is 2.5 percentage points more likely to be incarcerated compared to a similar white defendant.

Lower rates of incarceration during vacancies are robust to looking at judge deaths, and across both ordinary least squares and two-stage least squares specifications for senior status vacancies. Judge death results suggest that a ten percent vacant court is associated with a 0.67 percentage point decrease in incarceration, and two-stage least squares results suggest a 0.49 percentage point decrease in incarceration. This result indicates that prosecutors may be offering defendants more 
favorable plea deals in periods of judicial vacancy through the form of more non-incarcerative sentences, and likely through sentence bargaining rather than charge bargaining. Conversely, the probability of a probation-only sentence increases significantly during periods of vacancies. ${ }^{16}$

Given that more favorable plea deals are driven by changes in the incarceration margin, these favorable plea deals may be concentrated among lower priority offenses. Subsample results by major crime type reveal that increased rates of guilty pleas are concentrated among property, drug, and public order offenses, and lower rates of incarceration are concentrated among drug crimes (Appendix Table A4).

Recall that estimates of the impact of senior status vacancies are mechanically downwards biased toward zero because the preferred specification treats a senior status vacancy as equivalent to one full-time reduction in workload. In practice, many of these judges continue to hear cases to relieve their colleagues of caseload pressures, with some carrying a full caseload. While a senior status judge may decide how much to reduce his or her caseload based on court caseload pressures, I consider two alternative specifications that may more accurately reflect the reduction in judicial capacity from senior status vacancies. In columns 1 and 2 of Appendix Table A5, I present ordinary least squares and two-stage least squares estimates treating a senior status vacancy as a 0.75 full-time vacancy since senior status judges must maintain a minimum 25 percent workload. In columns 3 and 4 , I treat a senior status vacancy as a 0.37 full-time vacancy, relying on a prior 2003 survey of senior status district court judges, who reported hearing an average 63 percent full-time caseload (Yoon 2005). 17

Unsurprisingly, estimates of the impact of senior status vacancies on main outcomes are substantially larger under alternative specifications that more accurately reflect the reduction in judicial capacity. Across both ordinary least squares and two-stage least squares specifications, I find that senior status vacancies increase the probability of dismissal, the rate of guilty pleas, and decrease the rate of incarceration. Results treating a senior status vacancy as a 0.37 full-time reduction in capacity indicate that a ten percent vacant court increases the probability of dismissal by 0.31 percentage points, increases the probability of a guilty plea by 0.79 percentage points, and decreases the rate of incarceration by 1.31 percentage points, a 1.6 percent decrease from the mean rate and over 50 percent the magnitude of being a black defendant.

\footnotetext{
${ }^{16}$ Of course, sentencing outcomes may also capture any response of judges to vacancies. To the extent that judges bear a heavier caseload when there are vacancies on the court, sentencing outcomes may also reflect more hasty resolution of cases by judges. However, Epstein, Landes and Posner (2012) find no statistically significant effect of caseloads on the fraction of sentences that are below or above the Guidelines range.

${ }^{17}$ The data do not contain judge identifiers so there is no way of determining actual caseload of each senior status judge.
} 


\subsection{Prosecution Delays During Judicial Vacancies}

Finally, I explore whether judicial vacancies have increased case delays of defendants that are prosecuted (i.e. not declined or dismissed). In Table 9, I present evidence on the impact of vacancies on prosecution delays, as measured in years. Across all specifications, I find some evidence that vacancies have contributed to greater case delays from arrest to filing of charges, potentially reflective of greater screening, although estimates are economically small. Full sample ordinary least squares estimates indicate that a ten percent vacant court increases the time from arrest to filing by 0.002 years, or merely one additional day. However, vacancies somewhat correspond to reductions in delay from filing to disposition, with no significant net change in total delay from arrest to case disposition. The decrease in prosecution delays during periods of scarcity may result from the greater rate of plea bargains to avoid trial. Of course, judicial vacancies may also affect civil delays, particularly as criminal cases take precedence over civil cases due to the Sixth Amendment right to a speedy trial for criminal proceedings ${ }^{18}$

\subsection{Type of Defense Counsel}

Defense attorneys may also respond to judicial scarcity, and the previous identified effects may differ depending on whether a defendant has a court-appointed attorney, public defender, or has retained private counsel. Attorney type is correlated with performance (Iyengar 2007) and may become more prominent during periods of judicial scarcity.

In the dataset, 48 percent of clients retain private counsel, 16 percent are represented by public defenders, and 35 percent are represented by court-appointed private attorneys through the Criminal Justice Act (CJA) ${ }^{19}$ While many district courts use random assignment to assign cases between public defenders and CJA attorneys (Iyengar 2007), the decision to retain private counsel is not random. As a result, there may be unobservable differences between types of cases that private counsel take, compared to cases that public defenders are assigned 20

Table 10 presents ordinary least squares estimates for the main outcomes in the full sample, controlling for an interaction between the fraction of the court vacant and the type of defense counsel, where the omitted category is CJA court-appointed attorney. Consistent with Iyengar (2007), I find that public defenders perform significantly better than CJA attorneys. Although clients of public defenders generally plead guilty at a slightly higher rate, they are charged with fewer counts, and more likely to be charged with a misdemeanor at filing. Moreover, conviction at trial is significantly lower, as well as sentence length imposed, compared to CJA attorneys.

\footnotetext{
${ }^{18}$ On average, approximately 25 percent of a district court's caseload is comprised of criminal filings.

${ }^{19}$ I exclude the less than 1 percent of federal defendants who represent themselves, or pro se.

${ }^{20}$ In unreported results, I find no evidence of changes in the composition of defense counsel during periods of judicial vacancies.
} 
Clients of private counsel also fare better than clients of CJA attorneys. Private counsel clients are more likely to have their cases dismissed, are charged with fewer counts, less likely to be found guilty at trial, and more likely to receive a non-incarcerative sentence, compared to clients of CJA attorneys.

Differences in quality of representation by counsel type appear to magnify during periods of judicial scarcity. Clients of public defenders are more likely to have their cases dismissed conditional on prosecution during vacancies, with a ten percent vacancy rate corresponding to a 0.23 percentage point increase in the rate of dismissal, significantly higher than the rate of dismissals among clients of private counsel.

A ten percent vacancy rate is also associated with a 0.67 percentage point decrease in the incarceration rate for clients of private counsel, compared to clients of CJA attorneys. Differences in the incarceration rates of public defender and private counsel clients are not statistically significant. However, clients of private counsel receive significantly less prison time, compared to clients of CJA attorneys and public defenders, with a ten percent vacancy rate corresponding to almost 1.8 months less in prison, a four percent decrease from the mean sentence. These results suggest that criminal justice outcomes during periods of resource constraints have distributional consequences that depend on the quality of defense counsel.

\subsection{Robustness Checks}

In Appendix Table A6, I investigate the sensitivity of the results to alternative specifications. In column 1, I control for the absolute number of vacancies rather than the fraction of the court vacant and find same signed results compared to the preferred specification. In column 2, I control for the caseload (civil and criminal) per full-time active judge, with the total number of judgeships and caseloads for each district court indexed to 1997 values. Because both the number of authorized judgeships and total caseload are indexed to 1997 values, any variation in caseload per active judge stems from the vacancies themselves. Caseload per active judge ranges from less than 200 cases per year, to over 2,000 cases per year, with a standard deviation of 160 cases/year. I find that caseload per active judge is positively associated with the rate of dismissals and guilty pleas, and negatively associated with the rate of incarceration, suggesting that judicial vacancies have a larger effect in district courts with greater caseloads. Column 3 presents marginal results from a probit specification. Column 4 controls for district specific quartic time trends, and column 5 controls for district-by-disposition year fixed effects. Results are qualitatively similar across these specifications.

Next, I test for the exogeneity of the duration of vacancies. Theoretically, how quickly a successor is confirmed may be endogenous to unobservables correlated with case outcomes. For 
each vacancy, I construct a vacancy spell equal to the length of the median vacancy across all courts in that fiscal year. Measures of judicial capacity are then constructed using these alternative vacancy spells, with the total number of vacancies now ranging from zero to five in any monthyear. Column 6 presents results using these alternative vacancy spells. Point estimates across all outcomes are very similar to those using actual vacancy spells, although some estimates lose statistical significance due to the introduction of measurement error.

To further test whether the timing of vacancies is exogenous to unobservable resource constraints, I next employ a falsification test controlling for the fraction of the court vacant at the time the case is decided, as well as past and future vacancies in the court. I use the following specification:

$$
\begin{gathered}
Y_{i j d t m}=\beta_{0}+\beta_{1} * X_{i}+\theta_{1} * V_{d t, m-12}+\theta_{2} * V_{d t, m-9}+\theta_{3} * V_{d t, m-6}+\alpha * V_{d t m} \\
+\theta_{4} * V_{d t, m+6}+\theta_{5} * V_{d t, m+9}+\theta_{6} * V_{d t, m+12}+\kappa_{j}+\gamma_{d}+\delta_{t}+\lambda_{m}+\epsilon_{i j d t m}
\end{gathered}
$$

Again, the main coefficient of interest is $\alpha$, which captures the impact of judicial vacancies during the period the case is decided. If there are no omitted variables or trends that affect both judicial vacancies and case outcomes, past and future vacancies, controlling for current vacancies, should have no statistically significant power in predicting case outcomes. Because the average case is decided within six months, I control for the fraction of the court vacant at six, nine, and twelve months prior to and after filing of each case. Across all main outcomes, past and future vacancies are not predictive of case dispositions, consistent with the assumption that vacancies are exogenous (Figure 4). As expected, only the current number of judicial vacancies is correlated with main outcomes 21

\section{Conclusion}

In this paper, I explore the impact of resource constraints on the federal criminal justice system by exploiting variation in the number and timing of all district court vacancies from 1999-2010. Ordinary least squares and two-stage least squares estimates show that reductions in a court's judicial capacity are associated with prosecutors being more likely to decline and dismiss cases. Resulting prosecutions during judicial scarcity exhibit a higher rate of guilty pleas, and lower rate of incarceration, compared to cases prosecuted during periods with no vacancies. The magnitude of these findings is likely an underestimate of the true effect because courts have found ways to cushion the blow of vacancies, primarily through the continued service of senior status judges.

These results are consistent with both selection and treatment stories. Prosecutors screen out

\footnotetext{
${ }^{21}$ Results in tabular form are presented in Appendix Table A7.
} 
cases with weaker or more contestable evidence, but offer more favorable plea deals in resulting prosecutions to avoid going to trial. Prosecutorial behavior during periods of vacancy also has distributional consequences. Lower rates of incarceration and shorter prison sentences disproportionately accrue to defendants who can afford to retain private counsel, most commonly U.S. citizens and defendants who are married.

To the extent that prosecutors overcharge or prosecute cases with low social benefit, these results suggest that greater screening of cases upfront may reduce the pressure to plea bargain and reduce the likelihood of erroneous convictions. Even if filing a criminal charge does not result in conviction, the filing itself has large consequences on the suspect's well-being, reputation, and employment. Accordingly, greater screening of cases likely increases the welfare of arrestees.

On the other hand, if prosecutors are unable to investigate or forced to dismiss viable cases in the face of resource constraints, the deterrent and incapacitative effects of criminal sanctions may be reduced. To the extent that vacancies have reduced the effectiveness of criminal sanctions, recent reforms such as ending the filibuster on judicial nominees may prove beneficial to the justice system.

Overall, the current rate of vacancies has contributed to significantly fewer years in prison compared to a court system that is fully staffed. Assuming that senior status judges hear more than 60 percent of a full caseload, a ten percent vacant judiciary corresponds with a 1.31 percentage point lower rate of incarceration. With over 80,000 defendants sentenced every year in the federal system, this rate of vacancy corresponds to over 1000 fewer federal inmates each year, an annual decrease of 1.5 percent to the number of offenders entering federal prison, and a 14 percent reduction in the annual increase in the federal prison population. The welfare implications of these lost prison years depends on an assessment of the social value of these sanctions. Given the finding that reduced prison years stem largely from drug crimes, little may be lost in social welfare if criminalization of these offenses has minimal deterrent effect.

To better understand how resource constraints affect the incentives of prosecutors and other public officials, future work could explore the effects of other forms of constraints, such as prison capacity, and recent mandatory budget cuts known as sequestration. 


\section{References}

Alschuler, Albert, “The Prosecutor's Role in Plea Bargaining," University of Chicago Law Review, $1968,36,50-112$.

Association, American Bar, "Crisis in the Courts," 2011.

Ater, Itai, Yehonatan Givati, and Oren Rigbi, "Organizational Structure, Police Activity and Crime," Journal of Public Economics, 2014, 115, 62-71.

Bannon, Alicia, “The Impact of Judicial Vacancies on Federal Trial Courts," Technical Report, Brennan Center for Justice July 2014.

Barrow, Deborah J. and Gary Zuk, "An Institutional Analysis of Turnover in the Lower Federal Courts, 1900-1987," The Journal of Politics, 1990, 52, 457-476.

Bebchuk, Lucian A., "Litigation and Settlement Under Imperfect Information," The RAND Journal of Economics, 1984, 15, 404-415.

Beenstock, Michael and Yoel Haitovksy, "Does the Appointment of Judges Increase the Output of the Judiciary?," International Review of Law and Economics, 2004, 24 (3), 351-369.

Boylan, Richard, "Do the Sentencing Guidelines Influence the Composition of Federal Judges?," Journal of Legal Studies, 2004, 33, 231-253.

Boylan, Richard T. and Cheryl X. Long, "Salaries, Plea Rates, and the Career Objectives of Federal Prosecutors," Journal of Law and Economics, 2005, 48 (2), 627-651.

Braniff, William, "Local Discretion, Prosecutorial Choices and the Sentencing Guidelines," Federal Sentencing Reporter, 1993, 5, 309-313.

Choi, Stephen J., G. Mitu Gulati, and Eric A. Posner, "The Law and Policy of Judicial Retirement: An Empirical Study," 2011. U of Chicago Institute for Law \& Economics Olin Research Paper No. 550.

Cole, George F., "The Decision to Prosecute," Law and Society Review, 1970, 4 (3), 331-344.

da Silveira, Bernardo S., "Bargaining with Asymmetric Information: An Empirical Study of Plea Negotiations," November 2012.

Daughtey, Andrew F. and Jennifer F. Reinganum, "Settlement Negotiations with Two-Sided Asymmetric Information: Model Duality, Information Distribution, and Efficiency," International Review of Law and Economics, 1994, 14, 283-298.

Dayton, A. Kimberley, "Judicial Vacancies and Delay in the Federal Courts: An Empirical Evaluation, in Symposium, The Civil Justice Reform Act," St. John's Law Review, 1993, 67, 757-797.

de Figueiredo, John M., G. Gryski, E.H. Tiller, and G. Zuk, "Congress and the Political Expansion of the U.S. District Courts," American Law and Economics Review, 2000, 2, $107-125$.

Dixon, Jo, “The Organizational Context of Criminal Sentencing," American Journal of Sociology, 1995, 100 (5), 1157-1198. 
Easterbrook, Frank H., "Criminal Procedure as a Market System," Journal of Legal Studies, 1983, 12, 289-332.

Eisenstein, J., R. Fleming, and P. Nardulli, The Contours of Justice: Communities and Their Courts, Little and Brown, 1988.

Epstein, Lee and Jeffrey A. Segal, Advice and Consent: The Politics of Judicial Appointments, Oxford University Press, 2005.

, William M. Landes, and Richard A. Posner, The Behavior of Federal Judges: A Theoretical and Empirical Study of Rational Choice, Harvard University Press, 2012.

Fairman, Charles, “The Retirement of Federal Judges," Harvard Law Review, 1938, 51, 397-443.

Feeley, Malcolm M., "The Effects of Heavy Caseloads," 1975. Paper presented at the annual conference of the American Political Science Association.

Frase, Richard S., "The Decision to File Federal Criminal Charges: A Quantitative Study of Prosecutorial Discretion," University of Chicago Law Review, 1980, 47 (2), 246-330.

Gershowitz, Adam M. and Laura R. Killinger, "The State (Never) Rests: How Excessive Prosecutorial Caseloads Harm Criminal Defendants," Northwestern University Law Review, 2011, 105 (1), 261-301.

Glaeser, Edward L., Daniel P. Kessler, and Anne Morrison Piehl, "What Do Prosecutors Maximize? An Analysis of Drug Offenders and Concurrent Jurisdiction," American Law and Economics Review, 2000, 2, 259-290.

Gordon, Sanford C. and Gregory A. Huber, "Citizen Oversight and the Electoral Incentives of Criminal Prosecutors," American Journal of Political Science, 2002, 46 (2), 334-351.

and __ , "The Effect of Electoral Competitiveness on Incumbent Behavior," Quarterly Journal of Political Science, 2007, 2, 107-138.

Grossman, Gene M. and Michael L. Katz, "Plea Bargaining and Social Welfare," The American Economic Review, 1983, 73 (4), 749-757.

Heumann, Milton, Plea bargaining: The Experiences of Prosecutors, Judges, and Defense Attorneys, University of Chicago Press, 1978.

Huang, Bert I., "Lightened Scrutiny,” Harvard Law Review, 2011, 124 (5), 1109-1152.

Iverson, Benjamin, "Get in Line: Chapter 11 Restructuring in Crowded Bankruptcy Courts," March 2014.

Iyengar, Radha, "An Analysis of Attorney Performance in the Federal Indigent Defense System," 2007. NBER Working Paper 13187.

Landes, William M., "An Economic Analysis of the Courts," Journal of Law and Economics, 1971, 14, 61-107.

Lim, Claire S. H., "Preferences and Incentives of Appointed and Elected Public Officials: Evidence from State Trial Court Judges," American Economic Review, 2013, 103 (4), 13601397.

Mas, Alexandre, "Pay, Reference Points, and Police Performance," The Quarterly Journal of Economics, 2006, 121 (3), 783-821. 
Miller, Frank W., Prosecution: The Decision to Charge a Suspect with a Crime, Little and Brown, 1970.

Nardulli, Peter F., "The Caseload Controversy and the Study of Criminal Courts," Journal of Criminal Law and Criminology, 1979, 70, 89-101.

Rasmusen, Eric, Manu Raghav, and Mark Ramseyer, "Convictions versus Conviction Rates: The Prosecutor's Choice," American Law and Economics Review, 2009, 11 (1), 47-78.

Rehavi, M. Marit and Sonja B. Starr, "Racial Disparity in Federal Criminal Sentences," Journal of Political Economy, 2014, forthcoming.

Reinganum, Jennifer F., "Plea Bargaining and Prosecutorial Discretion," The American Economic Review, 1988, 78 (4), 713-728.

Robel, Lauren K., "Caseload and Judging: Judicial Adaptations to Caseloads," Brigham Young University Law Review, 1990, 1, 3-65.

Schmidhauser, John R., "When and Why Justices Leave the Supreme Courts," in "Politics of Age," University of Michigan, 1962, pp. 117-134.

Schulhofer, Stephen J., “Is Plea Bargaining Inevitable?," Harvard Law Review, 1984, 97, 1037 1107.

Scott, Robert E. and William J. Stuntz, "Plea Bargaining as Contract," Yale Law Journal, 1992, 101.

Smelcer, Susan N. and Denis S. Rutkus, "Vacancies on Article III District and Circuit Courts, 1977-2011: Data, Causes, and Implications," Technical Report R41942, Cong. Research Serv. July 2011.

Spriggs, James and Paul Wahlbeck, "Calling it Quits: Strategic Retirement on the Federal Courts of Appeals, 1893-1991," Political Research Quarterly, 1995, 48, 573-597.

Stemen, Don and Bruce Frederick, "Rules, Resources, and Relationships: Contextual Constraints on Prosecutorial Decision Making," Quinnipiac Law Review, 2013, 31, 1-83.

Ulmer, Jeffery T., "A Processual Order Approach to Studying Sentencing Guidelines: Contexts, Activities, and Consequences," Applied Behavioral Science Review, 1997, 5 (1), 81-100. and Brian Johnson, "Sentencing in Context: A Multilevel Analysis," Criminology, 2004, 42, 137-178.

Wheeler, Russell and Sarah Binder, "Do Judicial Emergencies Matter? Nomination and Confirmation Delay during the 111th Congress," Technical Report, Brookings Institution 2011.

Wright, Ronald F. and Marc L. Miller, "The Screening/Bargaining Tradeoff," Stanford Law Review, October 2002, 55 (1), 29-118.

Yoon, Albert, "As You Like It: Senior Federal Judges and the Political Economy of Judicial Tenure," Journal of Empirical Legal Studies, 2005, 2, 495-549.

, "Pensions, Politics, and Judicial Tenure: An Empirical Study of Federal Judges, 18692002," American Law and Economics Review, 2006, 8, 143-180. 


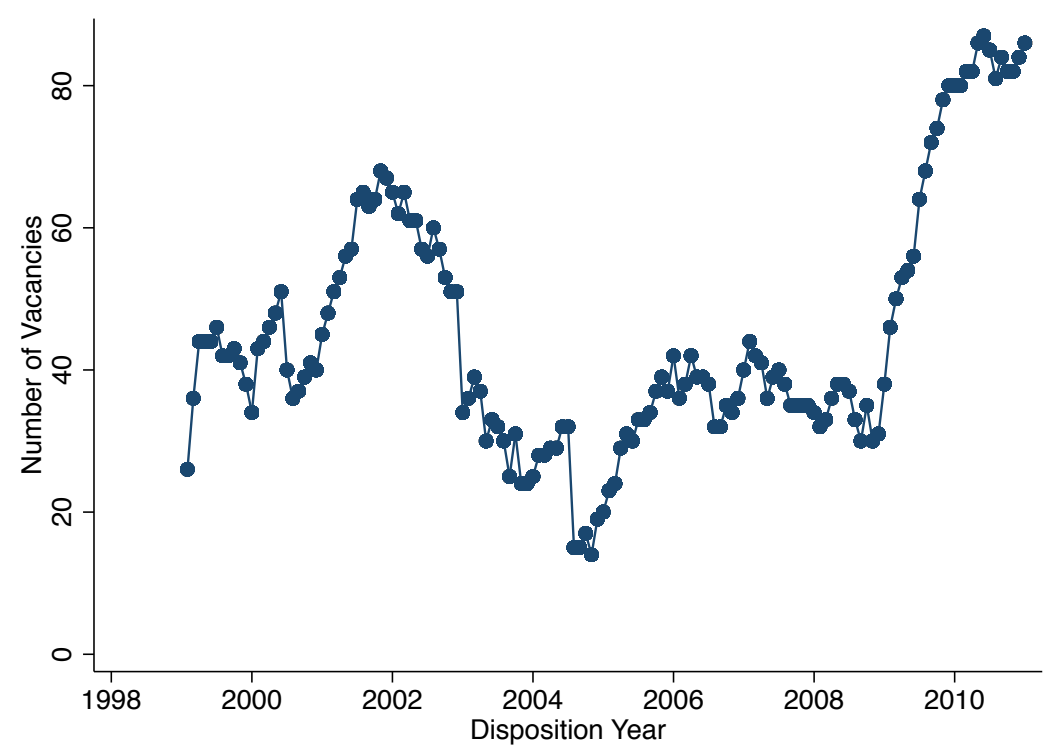

Figure 1. Number of Vacancies, By Month-Year

Notes: Data are from the Administrative Office of the United States Courts from 1999-2010. Average number of vacancies per month-year are displayed. Excludes vacancies created by new judgeships. 


\begin{tabular}{cccccc} 
& Vacancy & Arrest & Decline & & Confirmation \\
$t_{0}$ & $t_{1}$ & $t_{2}$ & $t_{3}$ & & $t_{4}$ \\
& Vacancy & & & & \\
& $t_{1}$ & Arrest & Charge & Dismiss & Confirmation \\
\hline$t_{0}$ & $t_{2}$ & $t_{3}$ & $t_{4}$ & $t_{5}$
\end{tabular}

Figure 2 


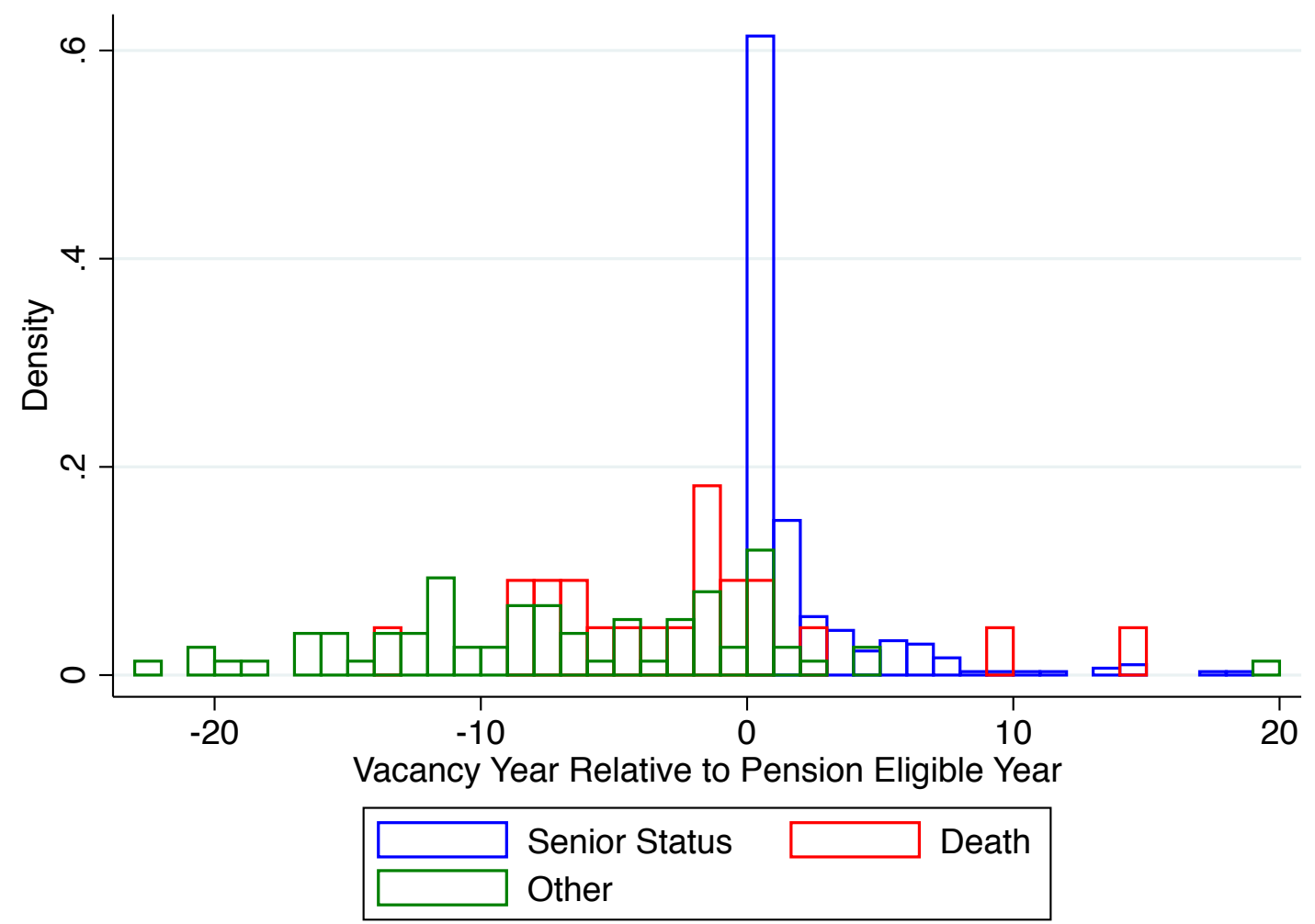

Figure 3. Distribution of Vacancies Relative to Pension Eligibility, by Type

Notes: Data are from the Administrative Office of the United States Courts from 1999-2010. Excludes vacancies created by new judgeships. 

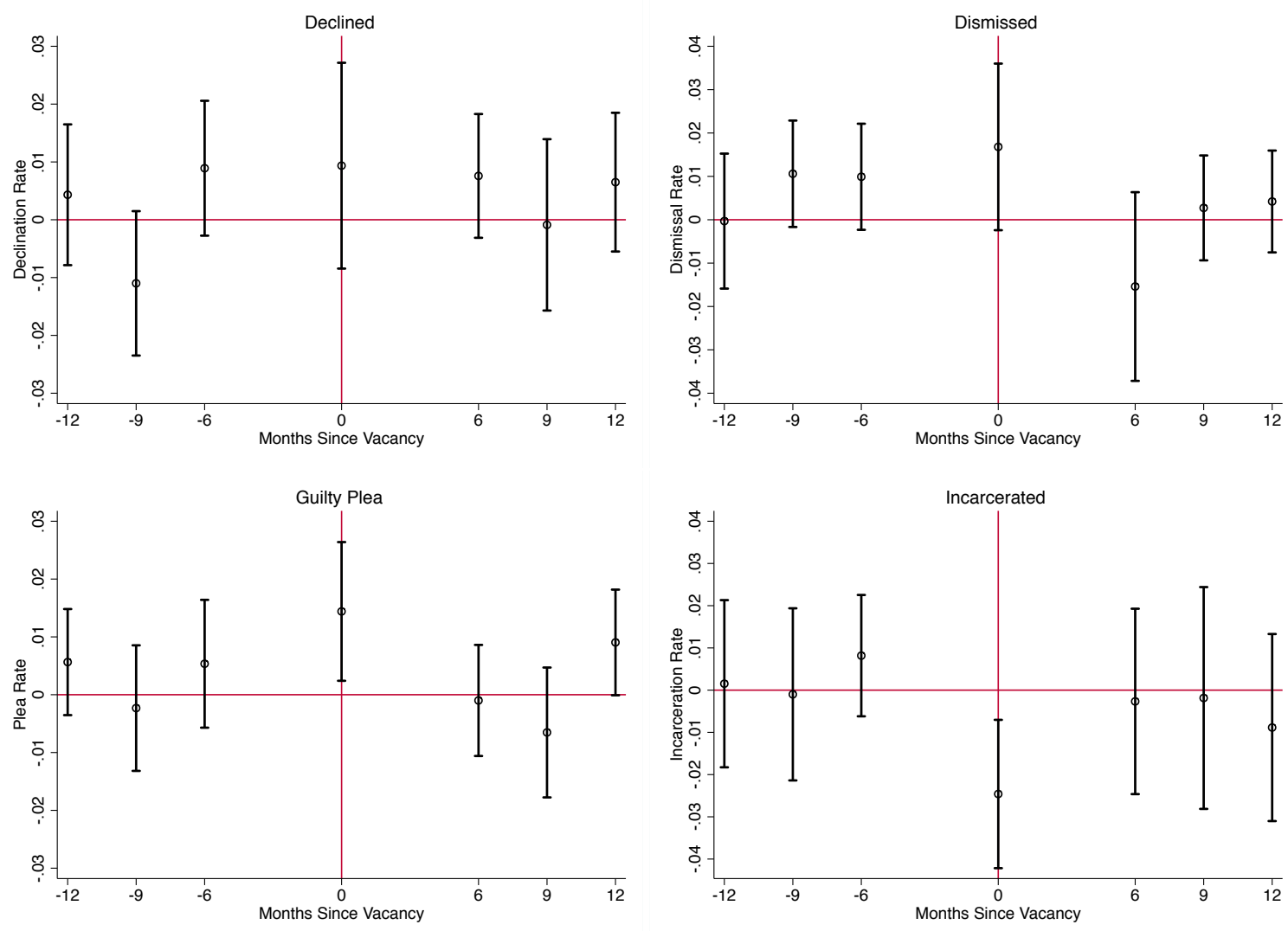

Figure 4. Falsification Tests

Notes: Data on declinations are from the matched Arrests and Suspects Concluded files for all suspects concluded from 1999-2010. Data on dismissals, plea rates, and incarceration rates are from the matched Arrests, Suspects Concluded, and Defendants Terminated files for all cases filed from 1999-2010. Coefficients are from regressions controlling for the fraction of the court vacant at the time the case is decided, as well as months before and months after. 
Table 1. Summary Statistics on Vacancy Type

\begin{tabular}{lcc}
\hline \hline Vacancy Reason & Observations & Percent \\
\hline Deceased & 22 & 5.08 \\
Disabled & 10 & 2.31 \\
Elevated & 27 & 6.24 \\
FJC Director & 2 & 0.46 \\
Impeached & 1 & 0.23 \\
New Position & 32 & 7.39 \\
Resigned & 21 & 4.85 \\
Retired & 15 & 3.46 \\
Senior & 303 & 79.98 \\
\hline Total & 433 & 100
\end{tabular}

Notes: Data are from the Administrative Office of the United States Courts from 1999-2010. 
Table 2. Summary Statistics on Confirmation Delay (in Years)

\begin{tabular}{lccccc}
\hline \hline Variable & Obs & Mean & Std. Dev. & Min & Max \\
\hline Delay from Vacancy to Nomination 1999-2004 (Yrs) & 243 & 1.082 & 1.501 & -.5 & 10.167 \\
Delay from Vacancy to Confirmation 1999-2004 (Yrs) & 243 & 1.465 & 1.496 & -.25 & 10.167 \\
Delay from Vacancy to Nomination 2005-2010 (Yrs) & 190 & 1.283 & 1.349 & -.667 & 9.083 \\
Delay from Vacancy to Confirmation 2005-2010 (Yrs) & 190 & 1.739 & 1.381 & -.083 & 9.083
\end{tabular}

Notes: Data are from the Administrative Office of the United States Courts from 1999-2010. 
Table 3. Summary Statistics

\begin{tabular}{lccccc}
\hline \hline \multirow{2}{*}{ Variable } & \multicolumn{7}{c}{ Panel A. Arrestees Linked to Suspects Concluded } & & \\
\cline { 2 - 6 } & Obs & Mean & Std. Dev. & Min & Max \\
\hline Black & 687723 & .158 & .364 & 0 & 1 \\
White & 687723 & .808 & .394 & 0 & 1 \\
Male & 687723 & .866 & .341 & 0 & 1 \\
U.S. Citizen & 626283 & .429 & .495 & 0 & 1 \\
Age & 674350 & 32.529 & 10.237 & 13 & 90 \\
Property & 687723 & .127 & .333 & 0 & 1 \\
Drugs & 687723 & .228 & .420 & 0 & 1 \\
Immigration & 687723 & .490 & .500 & 0 & 1 \\
Terminated by Magistrate & 687723 & .338 & .473 & 0 & 1 \\
Declined & 687723 & .031 & .173 & 0 & 1 \\
Removed or Transferred & 686820 & .018 & .132 & 0 & 1 \\
Deferred to State & 687719 & .004 & .061 & 0 & 1 \\
Delay from Arrest to Disposition (Yrs) & 687723 & .346 & .395 & 0 & 11 \\
\hline
\end{tabular}

Panel B. Defendants Filed in District Court

\begin{tabular}{lccccc} 
Variable & Obs & Mean & Std. Dev. & Min & Max \\
\hline Dismissed & 501618 & .046 & .209 & 0 & 1 \\
Guilty & 501618 & .948 & .222 & 0 & 1 \\
Plea & 501618 & .925 & .264 & 0 & 1 \\
Incarcerated & 501618 & .836 & .370 & 0 & 1 \\
Sentence (Mos) & 475709 & 44.695 & 65.142 & 0 & 3095 \\
Delay from Filing to Disposition (Yrs) & 501436 & .416 & .570 & 0 & 15.750 \\
\hline
\end{tabular}

\begin{tabular}{lccccc} 
Declined & 1381595 & .268 & .443 & 0 & 1 \\
Removed or Transferred & 1377318 & .021 & .144 & 0 & 1 \\
Deferred to State & 1381565 & .034 & .182 & 0 & 1 \\
Dismissed & 595713 & .049 & .215 & 0 & 1 \\
Guilty & 595713 & .934 & .248 & 0 & 1 \\
Plea & 595713 & .904 & .294 & 0 & 1 \\
\hline
\end{tabular}

Notes: Data in Panel A are from the matched Arrests and Suspects Concluded files for all cases filed from 1999-2010. Data in Panel B are from the matched Arrests, Suspects Concluded, and Defendants Terminated files for all cases filed from 1999-2010. Data in Panel C are from the universe of Suspects Concluded for all cases filed from 1999-2010. 


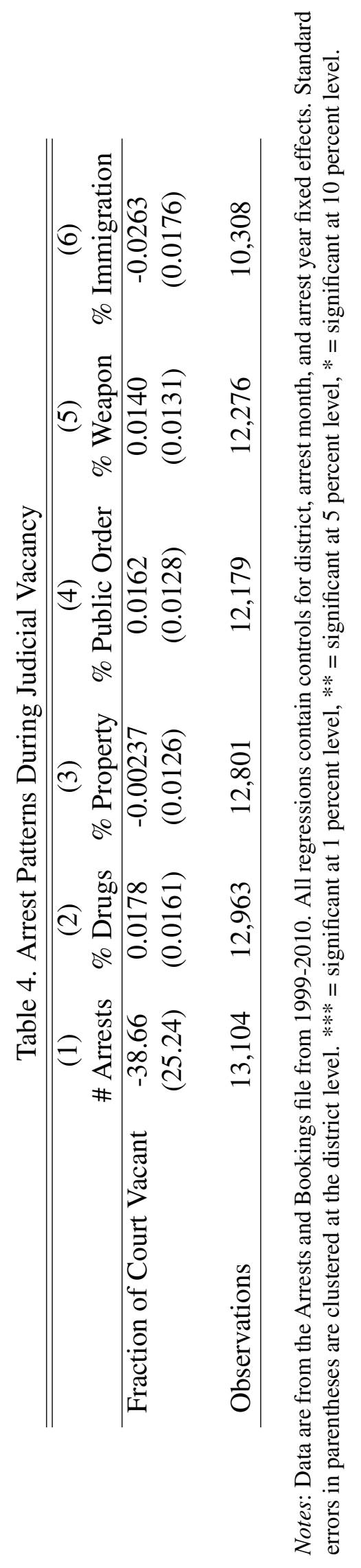


Table 5. Declinations and Dismissals

\begin{tabular}{lccccc}
\hline \hline & $\begin{array}{c}(1) \\
\text { Mean }\end{array}$ & $\begin{array}{c}(2) \\
\text { Full Sample } \\
\text { OLS }\end{array}$ & $\begin{array}{c}(3) \\
\text { Deaths } \\
\text { OLS/2SLS }\end{array}$ & $\begin{array}{c}(4) \\
\text { Senior Status } \\
\text { OLS }\end{array}$ & $\begin{array}{c}(5) \\
\text { Senior Status } \\
2 S L S\end{array}$ \\
\hline $\begin{array}{lccccc}\text { Dependent Variable } \\
\text { Declined }\end{array}$ & \multirow{2}{*}{0.031} & $0.0115^{*}$ & $0.0835^{* *}$ & 0.000157 & -0.00358 \\
& & $(0.00616)$ & $(0.0413)$ & $(0.00736)$ & $(0.0115)$ \\
& & & & & \\
Deferred to State & 0.004 & -0.00149 & 0.00529 & -0.00201 & -0.00158 \\
& & $(0.00153)$ & $(0.00570)$ & $(0.00195)$ & $(0.00265)$ \\
Dismissed & 0.046 & $0.0147^{* *}$ & $0.0625^{*}$ & $0.0151^{* *}$ & 0.0116 \\
& & $(0.00752)$ & $(0.0364)$ & $(0.00759)$ & $(0.0142)$ \\
& & & & & \\
Offense Controls? & & Yes & Yes & Yes & Yes \\
Demographic Controls? & & Yes & Yes & Yes & Yes \\
\hline
\end{tabular}

Notes: Data on declinations and deferrals are from the matched Arrests and Suspects Concluded files for all suspects concluded from 1999-2010 ( $\mathrm{N}=625,999)$. Data on dismissals are from the matched Arrests, Suspects Concluded, and Defendants Terminated files for all cases filed from 1999-2010 ( $\mathrm{N}=460,357)$. All regressions contain controls for district, disposition month, and disposition year fixed effects. Standard errors in parentheses are clustered at the district level. $* * *=$ significant at 1 percent level, $* *=$ significant at 5 percent level, $*=$ significant at 10 percent level. 
Table 6. Charging

\begin{tabular}{lccccc}
\hline \hline & $\begin{array}{c}(1) \\
\text { Mean }\end{array}$ & $\begin{array}{c}(2) \\
\text { Full Sample } \\
\text { OLS }\end{array}$ & $\begin{array}{c}\text { (3) } \\
\text { OLS/2SLS } \\
\text { OLS }\end{array}$ & $\begin{array}{c}\text { Senior Status } \\
\text { OLS }\end{array}$ & $\begin{array}{c}\text { Senior Status } \\
\text { 2SLS }\end{array}$ \\
\hline $\begin{array}{l}\text { Dependent Variable } \\
\text { Filed in Magistrate Court }\end{array}$ & 0.338 & -0.133 & -0.0442 & $-0.188^{*}$ & -0.227 \\
& & $(0.0937)$ & $(0.157)$ & $(0.109)$ & $(0.291)$ \\
Indictment & 0.767 & -0.0607 & -0.144 & -0.0611 & -0.114 \\
& & $(0.0431)$ & $(0.140)$ & $(0.0514)$ & $(0.101)$ \\
\# Counts & \multirow{2}{*}{2.509} & -0.119 & 0.0701 & -0.172 & -0.491 \\
& & $(0.159)$ & $(0.706)$ & $(0.178)$ & $(0.328)$ \\
Misdemeanor & 0.018 & 0.00333 & 0.00562 & 0.00461 & 0.00491 \\
& & $(0.00435)$ & $(0.0105)$ & $(0.00568)$ & $(0.0134)$ \\
& & & & & \\
Offense Controls? & & Yes & Yes & Yes & Yes \\
Demographic Controls? & & Yes & Yes & Yes & Yes \\
\hline
\end{tabular}

Notes: Data on filing in magistrate court are from the matched Arrests and Suspects Concluded files for all suspects concluded from 1999-2010 ( $\mathrm{N}=581,102)$. Data on indictments, counts, and misdemeanors are from the matched Arrests, Suspects Concluded, and Defendants Terminated files for all cases filed from 1999-2010 (N=439,799). All regressions contain controls for district, disposition month, and disposition year fixed effects. Standard errors in parentheses are clustered at the district level. $* * *=$ significant at 1 percent level, $* *=$ significant at 5 percent level, * $=$ significant at 10 percent level. 
Table 7. Plea Bargaining

\begin{tabular}{lccccc}
\hline \hline & $\begin{array}{c}(1) \\
\text { Mean }\end{array}$ & $\begin{array}{c}\text { Full Sample } \\
\text { OLS }\end{array}$ & $\begin{array}{c}\text { Deaths } \\
\text { OLS/2SLS }\end{array}$ & $\begin{array}{c}\text { Senior Status } \\
\text { OLS }\end{array}$ & $\begin{array}{c}\text { Senior Status } \\
\text { 2SLS }\end{array}$ \\
\hline $\begin{array}{l}\text { Dependent Variable } \\
\text { Guilty Adjudication }\end{array}$ & 0.948 & $\begin{array}{c}0.00552^{* * *} \\
(0.00184)\end{array}$ & $\begin{array}{c}-0.000545 \\
(0.00720)\end{array}$ & $\begin{array}{c}0.00614^{* * * *} \\
(0.00199)\end{array}$ & $\begin{array}{c}0.00910^{* * * *} \\
(0.00323)\end{array}$ \\
Guilty Plea & & & & & \\
& 0.925 & $0.0154^{* * *}$ & -0.0131 & $0.0150^{* * *}$ & $0.0291^{* * *}$ \\
& & $(0.00523)$ & $(0.0223)$ & $(0.00547)$ & $(0.0106)$ \\
Offense Change & 0.118 & -0.0107 & 0.00418 & -0.0118 & -0.00907 \\
& & $(0.0142)$ & $(0.0308)$ & $(0.0153)$ & $(0.0296)$ \\
Felony to Misdemeanor & 0.013 & $-0.0110^{*}$ & $-0.0242^{* *}$ & -0.00721 & 0.0160 \\
& & $(0.00659)$ & $(0.0103)$ & $(0.00738)$ & $(0.0264)$ \\
& & & & & \\
Offense Controls? & & Yes & Yes & Yes & Yes \\
Demographic Controls? & & Yes & Yes & Yes & Yes \\
\hline
\end{tabular}

Notes: Data are from the matched Arrests, Suspects Concluded, and Defendants Terminated files for all cases filed from 1999-2010 $(\mathrm{N}=439,799)$. All regressions contain controls for district, disposition month, and disposition year fixed effects. Standard errors in parentheses are clustered at the district level. $* * *=$ significant at 1 percent level, $* *=$ significant at 5 percent level, * $=$ significant at 10 percent level. 
Table 8. Sentence Outcomes

\begin{tabular}{lccccc}
\hline \hline & $(1)$ & $(2)$ & $(3)$ & $(4)$ & $(5)$ \\
& Mean & $\begin{array}{c}\text { Full Sample } \\
\text { OLS }\end{array}$ & $\begin{array}{c}\text { Deaths } \\
\text { OLS/2SLS }\end{array}$ & $\begin{array}{c}\text { Senior Status } \\
\text { OLS }\end{array}$ & $\begin{array}{c}\text { Senior Status } \\
\text { 2SLS }\end{array}$ \\
\hline $\begin{array}{l}\text { Dependent Variable } \\
\text { Incarcerated }\end{array}$ & 0.836 & $\begin{array}{c}-0.0287^{* *} \\
(0.0118)\end{array}$ & $\begin{array}{c}-0.0665^{*} \\
(0.0407)\end{array}$ & $\begin{array}{c}-0.0377^{* * *} \\
(0.0139)\end{array}$ & $\begin{array}{c}-0.0486^{*} \\
(0.0275)\end{array}$ \\
Sentence (Months) & 44.695 & 1.295 & -3.258 & 2.033 & -3.228 \\
& & $(2.139)$ & $(10.49)$ & $(2.425)$ & $(4.410)$ \\
Probation Only & 0.105 & $0.0302^{* * *}$ & 0.0322 & $0.0396^{* * *}$ & $0.0521^{* * *}$ \\
& & $(0.00939)$ & $(0.0402)$ & $(0.0111)$ & $(0.0193)$ \\
Fine Only & 0.041 & $-0.00358^{* *}$ & -0.00471 & $-0.00317^{*}$ & -0.00519 \\
& & $(0.00155)$ & $(0.00419)$ & $(0.00170)$ & $(0.00368)$ \\
Offense Controls? & & & & & \\
Demographic Controls? & & Yes & Yes & Yes & Yes \\
\hline
\end{tabular}

Notes: Data are from the matched Arrests, Suspects Concluded, and Defendants Terminated files for all cases filed from 1999-2010 $(\mathrm{N}=439,799)$. All regressions contain controls for district, disposition month, and disposition year fixed effects. Standard errors in parentheses are clustered at the district level. $* * *=$ significant at 1 percent level, $* *=$ significant at 5 percent level, * $=$ significant at 10 percent level. 
Table 9. Disposition Time (in years)

\begin{tabular}{|c|c|c|c|c|c|}
\hline & $\begin{array}{l}(1) \\
\text { Mean }\end{array}$ & $\begin{array}{c}\text { (2) } \\
\text { Full Sample } \\
\text { OLS }\end{array}$ & $\begin{array}{c}(3) \\
\text { Deaths } \\
\text { OLS/2SLS }\end{array}$ & $\begin{array}{c}(4) \\
\text { Senior Status } \\
\text { OLS }\end{array}$ & $\begin{array}{c}(5) \\
\text { Senior Status } \\
\text { 2SLS }\end{array}$ \\
\hline $\begin{array}{l}\text { Dependent Variable } \\
\text { Arrest to Filing }\end{array}$ & 0.068 & $\begin{array}{c}0.0168^{*} \\
(0.00933)\end{array}$ & $\begin{array}{c}0.0119 \\
(0.0298)\end{array}$ & $\begin{array}{c}0.0161 \\
(0.0118)\end{array}$ & $\begin{array}{c}0.0385 * * \\
(0.0195)\end{array}$ \\
\hline Filing to Disposition & 0.416 & $\begin{array}{l}-0.0752^{*} \\
(0.0417)\end{array}$ & $\begin{array}{l}-0.0381 \\
(0.171)\end{array}$ & $\begin{array}{l}-0.0272 \\
(0.0512)\end{array}$ & $\begin{array}{l}-0.122 * \\
(0.0705)\end{array}$ \\
\hline Arrest to Disposition & 0.403 & $\begin{array}{l}-0.0584 \\
(0.0454)\end{array}$ & $\begin{array}{l}-0.0262 \\
(0.167)\end{array}$ & $\begin{array}{l}-0.0111 \\
(0.0556)\end{array}$ & $\begin{array}{l}-0.0839 \\
(0.0757)\end{array}$ \\
\hline Offense Controls? & & Yes & Yes & Yes & Yes \\
\hline Demographic Controls? & & Yes & Yes & Yes & Yes \\
\hline
\end{tabular}

Notes: Data are from the matched Arrests, Suspects Concluded, and Defendants Terminated files for all cases filed from 1999-2010 $(\mathrm{N}=439,799)$. All regressions contain controls for district, disposition month, and disposition year fixed effects. Standard errors in parentheses are clustered at the district level. $* * *=$ significant at 1 percent level, $* *=$ significant at 5 percent level, * $=$ significant at 10 percent level. 


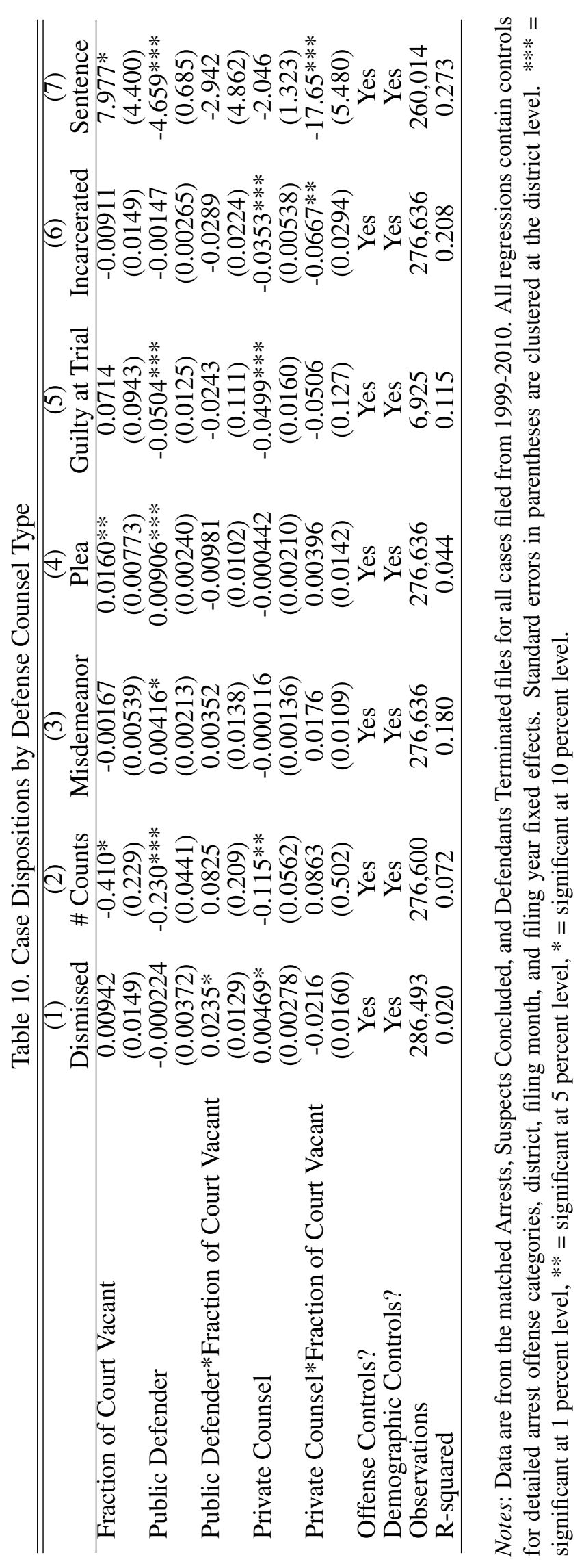




\section{Appendix A}

Table A1. Vacancies by District Court, 1999-2010

\begin{tabular}{|c|c|}
\hline District Court & Number of Vacancies \\
\hline Maine & 3 \\
\hline Masschusetts & 2 \\
\hline New Hampshire & 1 \\
\hline Rhode Island & 2 \\
\hline Puerto Rico & 4 \\
\hline Connecticut & 3 \\
\hline New York - Northern & 4 \\
\hline New York - Eastern & 10 \\
\hline New York - Southern & 20 \\
\hline New York - Western & 1 \\
\hline Vermont & 1 \\
\hline Delaware & 3 \\
\hline New Jersey & 13 \\
\hline Pennsylvania - Eastern & 17 \\
\hline Pennsylvania - Middle & 5 \\
\hline Pennsylvania - Western & 9 \\
\hline Maryland & 6 \\
\hline North Carolina - Eastern & 3 \\
\hline North Carolina - Middle & 3 \\
\hline North Carolina - Western & 3 \\
\hline South Carolina & 5 \\
\hline Virginia - Eastern & 6 \\
\hline Virginia - Western & 2 \\
\hline West Virginia - Northern & 2 \\
\hline West Virginia - Southern & 2 \\
\hline Alabama - Northern & 4 \\
\hline Alabama - Middle & 2 \\
\hline Alabama - Southern & 3 \\
\hline Florida - Northern & 2 \\
\hline Florida - Middle & 7 \\
\hline Florida - Southern & 7 \\
\hline Georgia - Northern & 7 \\
\hline Georgia - Middle & 3 \\
\hline Georgia - Southern & 2 \\
\hline Louisiana - Eastern & 5 \\
\hline Louisiana - Western & 4 \\
\hline Mississippi - Northern & 3 \\
\hline Mississippi - Southern & 5 \\
\hline Texas - Northern & 5 \\
\hline Texas - Eastern & 5 \\
\hline Texas - Southern & 8 \\
\hline Texas - Western & 6 \\
\hline Kentucky - Eastern & 4 \\
\hline Kentucky - Western & 0 \\
\hline Michigan - Eastern & 8 \\
\hline Michigan - Western & 3 \\
\hline
\end{tabular}


Table A1. Vacancies by District Court, 1999-2010

\begin{tabular}{|c|c|}
\hline District Court & Number of Vacancies \\
\hline Ohio - Northern & 6 \\
\hline Ohio - Southern & 5 \\
\hline Tennessee - Eastern & 4 \\
\hline Tennessee - Middle & 2 \\
\hline Tennessee - Western & 3 \\
\hline Illinois - Northern & 17 \\
\hline Illinois - Central & 3 \\
\hline Illinois - Southern & 1 \\
\hline Indiana - Northern & 4 \\
\hline Indiana - Southern & 3 \\
\hline Wisconsin - Eastern & 0 \\
\hline Wisconsin - Western & 2 \\
\hline Arkansas - Eastern & 4 \\
\hline Arkansas - Western & 2 \\
\hline Iowa - Northern & 1 \\
\hline Iowa - Southern & 2 \\
\hline Minnesota & 3 \\
\hline Missouri - Eastern & 4 \\
\hline Missouri - Western & 2 \\
\hline Nebraska & 1 \\
\hline North Dakota & 2 \\
\hline South Dakota & 3 \\
\hline Arizona & 4 \\
\hline California - Northern & 7 \\
\hline California - Eastern & 5 \\
\hline California - Central & 21 \\
\hline California - Southern & 6 \\
\hline Hawaii & 2 \\
\hline Idaho & 0 \\
\hline Montana & 2 \\
\hline Nevada & 4 \\
\hline Oregon & 4 \\
\hline Washington - Eastern & 3 \\
\hline Washington - Western & 6 \\
\hline Colorado & 7 \\
\hline Kansas & 3 \\
\hline New Mexico & 3 \\
\hline Oklahoma - Northern & 3 \\
\hline Oklahoma - Eastern & 2 \\
\hline Oklahoma - Western & 3 \\
\hline Utah & 4 \\
\hline Wyoming & 1 \\
\hline District of Columbia & 9 \\
\hline Virgin Islands & 1 \\
\hline Guam & 0 \\
\hline Alaska & 2 \\
\hline Louisiana - Middle & 2 \\
\hline
\end{tabular}

Notes: Data are from the Administrative Office of the United States Courts from 1999-2010. Total vacancies (N=402) exclude vacancies due to a new judgeship. 
Table A2. First Stage - Pension Eligibility

\begin{tabular}{lc}
\hline \hline & $\begin{array}{c}(1) \\
\text { No. of Vacancies }\end{array}$ \\
\hline Predicted No. of Vacancies & $0.653^{* * *}$ \\
& $(0.0309)$ \\
& \\
Offense Controls? & Yes \\
Demographic Controls? & Yes \\
Observations & 625,995 \\
\hline
\end{tabular}

Notes: Data are from the matched Arrests and Suspects Concluded files for all suspects concluded from 1999-2010. All regressions contain controls for detailed arrest offense categories, district, disposition month, and disposition year fixed effects. Standard errors in parentheses are clustered at the district level. $* * *=$ significant at 1 percent level, $* *=$ significant at 5 percent level, $*$ = significant at 10 percent level. 
Table A3. Main Results - Other Coefficients

\begin{tabular}{lcccc}
\hline \hline & $(1)$ & $(2)$ & $(3)$ & $(4)$ \\
& Declined & Dismissed & Guilty Plea & Incarcerated \\
\hline Black & 0.00605 & $0.00522^{* * *}$ & $-0.0202^{* * *}$ & $0.0250^{* * *}$ \\
& $(0.00458)$ & $(0.00148)$ & $(0.00144)$ & $(0.00351)$ \\
Male & $0.0117 * * *$ & $-0.0154^{* * *}$ & $-0.00796^{* * *}$ & $0.123^{* * *}$ \\
& $(0.00132)$ & $(0.00178)$ & $(0.00118)$ & $(0.00657))$ \\
U.S. Citizen & $0.0173^{* * *}$ & 0.00149 & 0.000933 & $-0.0714 * * *$ \\
& $(0.00161)$ & $(0.00211)$ & $(0.00164)$ & $(0.00461)$ \\
Offense Controls? & Yes & Yes & Yes & Yes \\
Demographic Controls? & Yes & Yes & Yes & Yes \\
Observations & 625,999 & 460,989 & 439,799 & 439,799 \\
\hline
\end{tabular}

Notes: Data from column (1) are from the matched Arrests and Suspects Concluded files for all suspects concluded from 1999-2010. Data from columns (2)-(4) are from the matched Arrests, Suspects Concluded, and Defendants Terminated files for all cases filed from 1999-2010. All regressions contain controls for district, disposition month, and disposition year fixed effects. Standard errors in parentheses are clustered at the district level. $* * *=$ significant at 1 percent level, ${ }^{* *}=$ significant at 5 percent level, $*=$ significant at 10 percent level. 


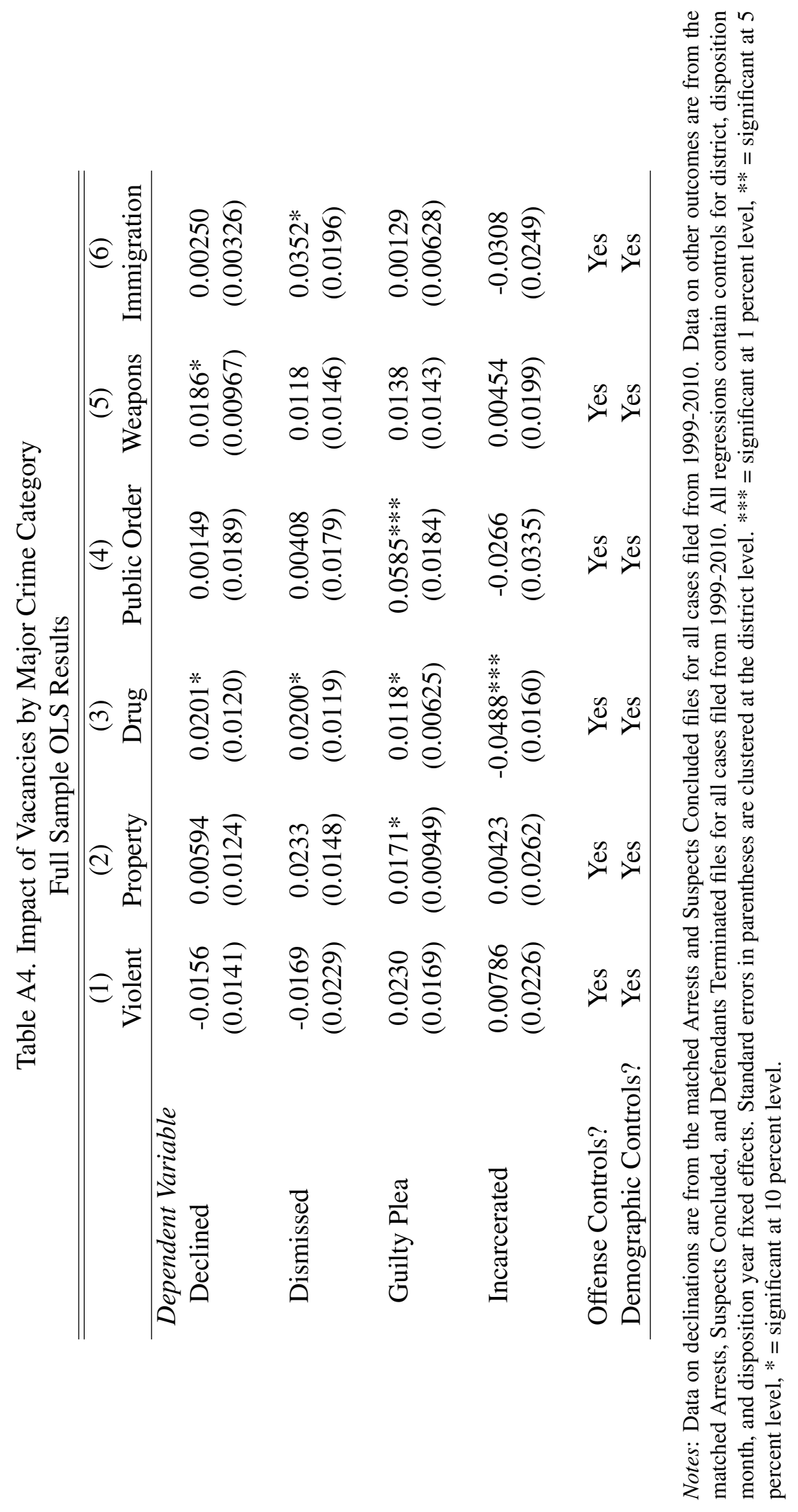


Table A5. Alternative Specifications

\begin{tabular}{lcccc}
\hline \hline & $(1)$ & $(2)$ & $(3)$ & $(4)$ \\
& $\begin{array}{c}\text { Senior OLS } \\
\text { Dependent Variable }\end{array}$ & $\begin{array}{c}\text { Senior 2SLS } \\
0.75\end{array}$ & $\begin{array}{c}\text { Senior OLS } \\
0.37\end{array}$ & $\begin{array}{c}\text { Senior 2SLS } \\
0.37\end{array}$ \\
\hline $\begin{array}{l}\text { Declined } \\
\text { Dismissed }\end{array}$ & 0.000209 & -0.00477 & 0.000424 & -0.00966 \\
& $(0.00981)$ & $(0.0154)$ & $(0.0199)$ & $(0.0312)$ \\
& & & & \\
Guilty Plea & $0.0201 *$ & 0.0155 & $0.0407 *$ & 0.0313 \\
& $(0.0101)$ & $(0.0189)$ & $(0.0205)$ & $(0.0383)$ \\
& & & & \\
Incarcerated & $0.0200^{* * *}$ & $0.0388^{* * *}$ & $0.0406^{* * *}$ & $0.0787 * * *$ \\
& $(0.00729)$ & $(0.0142)$ & $(0.0148)$ & $(0.0287)$ \\
& & & & \\
& $-0.0503 * * *$ & $-0.0648 *$ & $-0.102 * * *$ & $-0.131^{*}$ \\
Offense Controls? & $(0.0185)$ & $(0.0367)$ & $(0.0375)$ & $(0.0744)$ \\
Demographic Controls? & Yes & Yes & Yes & Yes \\
\hline
\end{tabular}

Notes: Data on declinations are from the matched Arrests and Suspects Concluded files for all suspects concluded from 1999-2010 (N=625,999). Data on other outcomes are from the matched Arrests, Suspects Concluded, and Defendants Terminated files for all cases filed from 1999-2010 ( $\mathrm{N}=439,799)$. All regressions contain controls for district, disposition month, and disposition year fixed effects. Standard errors in parentheses are clustered at the district level. $* * *=$ significant at 1 percent level, $* *=$ significant at 5 percent level, $*=$ significant at 10 percent level. 


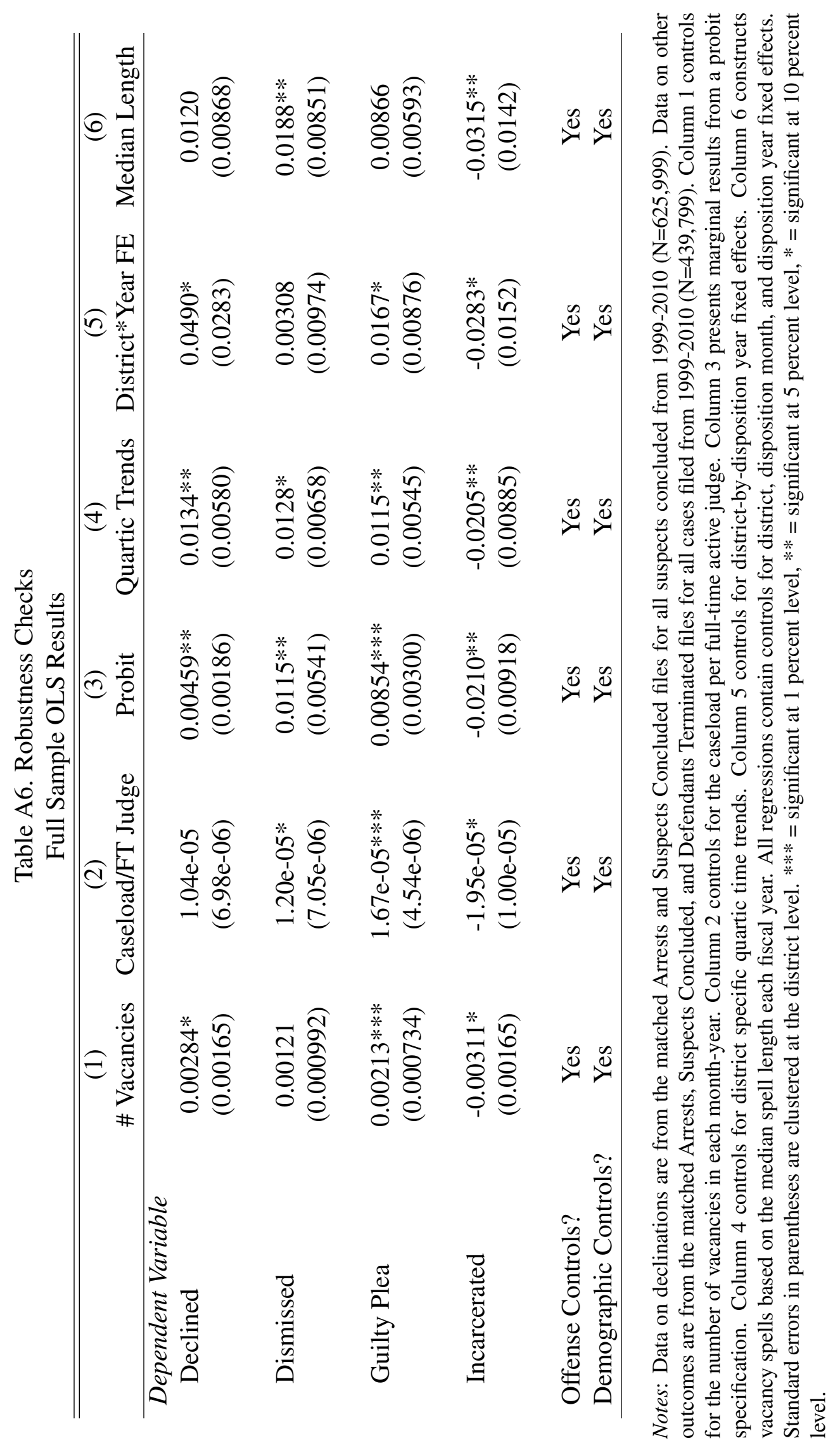


Table A7. Falsification Test

\begin{tabular}{lcccc}
\hline \hline & $(1)$ & $(2)$ & $(3)$ & $(4)$ \\
& Declined & Dismissed & Guilty Plea & Incarcerated \\
\hline Fraction of Court Vacant 12 Mos Before & 0.00432 & -0.000313 & 0.00564 & 0.00152 \\
& $(0.00621)$ & $(0.00794)$ & $(0.00468)$ & $(0.0101)$ \\
Fraction of Court Vacant 9 Mos Before & $-0.0110^{*}$ & $0.0106^{*}$ & -0.00232 & -0.00100 \\
& $(0.00637)$ & $(0.00626)$ & $(0.00554)$ & $(0.0104)$ \\
Fraction of Court Vacant 6 Mos Before & 0.00891 & 0.00991 & 0.00535 & 0.00817 \\
& $(0.00595)$ & $(0.00624)$ & $(0.00564)$ & $(0.00733)$ \\
Fraction of Court Vacant & 0.00935 & $0.0168^{*}$ & $0.0144^{* *}$ & $-0.0246^{* * *}$ \\
& $(0.00908)$ & $(0.00980)$ & $(0.00612)$ & $(0.00896)$ \\
Fraction of Court Vacant 6 Mos After & 0.000758 & -0.0154 & -0.000995 & -0.00267 \\
& $(0.00546)$ & $(0.0111)$ & $(0.00490)$ & $(0.0112)$ \\
Fraction of Court Vacant 9 Mos After & -0.000885 & 0.00273 & -0.00653 & -0.00186 \\
& $(0.00756)$ & $(0.00617)$ & $(0.00573)$ & $(0.0134)$ \\
Fraction of Court Vacant 12 Mos After & 0.00650 & 0.00421 & $0.00904^{*}$ & -0.00886 \\
& $(0.00612)$ & $(0.00599)$ & $(0.00466)$ & $(0.0113)$ \\
Offense Controls? & Yes & Yes & Yes & Yes \\
Demographic Controls? & Yes & Yes & Yes & Yes \\
Observations & 625,876 & 460,211 & 439,661 & 439,661 \\
R-squared & 0.103 & 0.021 & 0.058 & 0.224 \\
\hline
\end{tabular}

Notes: Data from column 1 are from the matched Arrests and Suspects Concluded files for all suspects concluded from 1999-2010. Data in columns 2-4 are from the matched Arrests, Suspects Concluded, and Defendants Terminated files for all cases filed from 1999-2010. All regressions contain controls for district, filing month, and filing year fixed effects. Standard errors in parentheses are clustered at the district level. $* * *=$ significant at 1 percent level, $* *=$ significant at 5 percent level, $*$ = significant at 10 percent level. 


\section{Appendix B}

Model Setup

In the model, there are two parties: the prosecutor and the defendant. Suppose that the utility functions of the two parties are linear with respect to the sentence imposed. The defendant seeks to minimize the sentence imposed and the prosecutor seeks to maximize the sanctions imposed, and both parties are risk neutral (Landes 1971) ${ }^{22}$ I assume that arrests are a random process following Reinganum (1988), such that arrests do not reveal any information about the defendant.

There are three main stages in the model. First, the prosecutor unilaterally decides whether to prosecute from a pool of arrested suspects. Second, conditional on prosecution, the prosecutor and defendant bargain over the sentence. The prosecutor makes an offer and the defendant decides whether or not to accept the plea ${ }^{23}$ If the defendant rejects the plea, the parties go to trial in the third stage. See Appendix Figure 1 for a game tree diagram.

Specifically, prosecutors observe an exogenous signal of the strength or litigative merit of the case, $\pi$. I assume that $\pi$ is common knowledge. In contrast, the defendant has private information about his culpability, $\alpha$. For tractability, I assume that $\pi$ and $\alpha$ are uncorrelated, such that the prosecutor can have strong or weak evidence, regardless of the defendant's true culpability ${ }^{24}$ For technical purposes, assume the $\alpha$ is drawn from a distribution $\mathrm{F}$ distributed over the interval ( $\underline{\alpha}$, $\bar{\alpha})$, and $\pi$ is drawn from a distribution $\mathrm{G}$ distributed over the interval $(\underline{\pi}, \bar{\pi})$. F and $\mathrm{G}$ are twice differentiable, with the associated density functions $f$ and $g$ strictly positive over the respective intervals 25

The probability of conviction at trial, $\theta(\pi, \alpha)$, is a function of both $\pi$ and $\alpha$, such that $\theta_{\pi}>0$ and $\theta_{\alpha}>0$. Intuitively, the greater the strength of the prosecutor's case, the higher likelihood of conviction at trial, holding defendant type constant. Similarly, the more culpable the defendant, the higher probability of conviction at trial. Assume that $\theta(\pi, \alpha) \subseteq(0,1)$ for all values of $\pi$ and $\theta$.

Upon filing charges, the prosecutor pays prosecution costs of $k$, associated with initiating proceedings (arraignment, bail, grand jury) and garnering evidence. If a prosecutor does not file charges, the arrested suspect is released ${ }^{26}$ If a defendant is convicted at trial, a sentence $x$ is im-

\footnotetext{
${ }^{22}$ See Glaeser, Kessler, and Piehl (2000) or Grossman and Katz (1983) for alternative measures of the prosecutor's objective function. Grossman and Katz assume that prosecutors care about expected sentence length maximization, but also suffer disutility from imposing penalties on innocent defendants. See Reinganum (1988) for a similar model of correlated two-sided asymmetric information in plea bargaining, yielding the prediction that sufficiently weak cases are dismissed.

${ }^{23}$ Technically, the prosecutor can still dismiss the case after charges are filed, equivalent to a plea offer of zero.

${ }^{24}$ Priest and Klein (1984) also assume independent signals of trial success in the civil context.

${ }^{25}$ I also assume that the hazard rate $\frac{f}{[1-F]}$ is increasing in $\alpha$ in order to rule out multiple equilibria. See Bebchuk (1984).

${ }^{26}$ In reality, the suspect may also be charged in the state system in lieu of federal prosecution.
} 
posed. The prosecutor pays additional costs of $c_{p}$ (in utility terms) in going to trial and the defendant expends trial costs of $c_{d}$ (in utility terms). Prosecutorial trial costs include costs of witnesses, utilizing courtroom personnel, and the general opportunity cost given limited resources. A prosecutor's trial costs may also include costly forensic analysis and expert witnesses. A defendant's costs can consist of attorneys fees and time costs associated with awaiting trial or sentencing. The sentence length imposed at trial, $x$, and $\operatorname{costs} c_{p}$ and $c_{d}$ are assumed to be known to both parties ${ }^{27}$

In plea bargaining, the prosecutor makes a take-it-or-leave-it offer of sentence length $s$ in exchange for a guilty plea. If the defendant accepts the plea, the prosecutor receives utility of $s$ and the defendant receives utility of $-s$. If the defendant rejects the plea, the case goes to trial. Assume that if a plea deal is rejected, a prosecutor commits to going to trial, such that $\theta(\underline{\pi}, \underline{\alpha}) x \geq c_{p}$. In practice, this assumption is plausible given reputational incentives of prosecutors. If convicted, the prosecutor receives $x-c_{p}$ and defendant receives $-x-c_{d}$. If acquitted, the prosecutor receives $-c_{p}$ and the defendant $-c_{d}$.

\section{Equilibrium}

The game proceeds in the three stages as described. Note that because the costs of trial, $c_{p}$ and $c_{d}$, the sentence length if convicted, $x$, and the strength of evidence, $\pi$, are known to both parties, the defendant can perfectly infer the strength of the prosecutor's case. 28

Solving by backwards induction to find the perfect Bayesian equilibrium, we begin with the defendant's decision of whether to accept or reject the plea offer. A defendant with culpability $\alpha$ will accept the prosecutor's offer of $s$ if $s \leq \theta(\pi, \alpha) x+c_{d}$ or if

$$
\frac{s-c_{d}}{x} \leq \theta(\pi, \alpha)
$$

Because $\theta$ is increasing in $\alpha$, the defendant's decision rule results in a cutoff $\alpha(s)$, characterized as the threshold defendant, such that for every plea offer $s$, defendants with $\alpha<\alpha(s)$ reject the plea, and defendants with $\alpha \geq \alpha(s)$ accept the plea. Intuitively, defendants who are relatively more "innocent" are less likely to plead guilty, compared to more guilty defendants.

Example: Suppose $\theta(\pi, \alpha)=\pi \alpha$, where $\pi \subseteq(0,1)$ and $\alpha \subseteq(0,1)$. The defendant's decision

\footnotetext{
${ }^{27}$ It is relatively straightforward to extend the model to allow the sentence imposed at trial to increase with the strength of the prosecutor's case, yielding similar predictions. See Daughety and Reinganum (1994) for two-sided asymmetric information in civil litigation where the plaintiff knows the level of damages, but the defendant knows the probability he will be held liable for damages.

${ }^{28} \mathrm{~A}$ more complicated model of two-sided asymmetric information would yield a similar pure separating equilibrium in which the prosecutor's offer revealed the strength of the case under additional refinements. See Daughety and Reinganum (1994).
} 
rule is to accept the plea offer if $s \leq(\pi \alpha) x+c_{d}$, or

$$
\frac{s-c_{d}}{\pi x} \leq \alpha
$$

Proposition 1: The probability of acceptance of a plea offer is decreasing in plea offer $s$, increasing in defendant trial costs $c_{d}$, increasing in sentence at trial $x$, and increasing in the strength of the prosecutor's case $\pi$.

Proofs: Given expression (1) and the assumption that $\theta$ is continuously increasing in $\alpha$ and $\pi$, it is straightforward to show that higher $s$ in the left-hand expression will yield a higher $\alpha(s)$ threshold on the right-hand side, resulting in a lower probability of acceptance, such that $\alpha_{s}(s)>0$. Similarly, increases in $c_{d}$ and $x$ lower the left-hand expression, resulting in a lower $\alpha(s)$ threshold, increasing the probability of acceptance. An increase in $\pi$ increases the equilibrium probability of conviction $\theta$, such that the threshold for acceptance $\alpha(s)$ is lower, leading to a higher probability of acceptance, such that $\alpha_{\pi}(s)<0$. Assume that $\alpha_{s \pi}(s)<0$ such that the effect of a higher plea offer on the defendant's threshold type is reduced the greater the strength of the prosecutor's case.

Conditional on $\pi$, the prosecutor's maximizes his expected utility by anticipating the defendant's behavior:

$$
\max _{s}\{1-F[\alpha(s)]\} s+F[\alpha(s)]\left\{-c_{p}+x \frac{\int_{\underline{\alpha}}^{\alpha(s)} \theta(\pi, \alpha) f(\alpha) d \alpha}{F[\alpha(s)]}\right\}
$$

With probability $1-F[\alpha(s)]$, a defendant will accept the prosecutor's plea offer $s$, and with probability $F[\alpha(s)]$, the defendant will reject the plea offer. Upon rejecting, the prosecutor expends costs of going to trial, $c_{p}$, and receives an expected sentence of $x \int_{\underline{\alpha}}^{\alpha(s)} \theta(\pi, \alpha) f(\alpha) d \alpha$.

The optimal plea sentence $s^{\star}$, and equivalently optimal defendant threshold $\alpha^{\star}$, satisfies the first order condition:

$$
\begin{array}{r}
1-F\left[\alpha\left(s^{\star}\right)\right]=\left(c_{p}+c_{d}\right) f\left[\alpha\left(s^{\star}\right)\right] \alpha_{s}\left(s^{\star}\right) \\
\text { or } \\
\frac{f\left[\alpha\left(s^{\star}\right)\right]}{1-F\left[\alpha\left(s^{\star}\right)\right]} \alpha_{s}\left(s^{\star}\right)=\frac{1}{c_{p}+c_{d}}
\end{array}
$$

The first term of expression (3) represents the marginal benefit to the prosecutor of an increase in the offered plea sentence, that is, a higher sentence length with probability $1-F\left[\alpha\left(s^{\star}\right)\right]$. The second term represents the marginal cost to the prosecutor of an increase in the plea offer, equal to the increased probability of going to trial, $f\left[\alpha\left(s^{\star}\right)\right] \alpha_{s}\left(s^{\star}\right)$, resulting in a loss of $c_{p}+c_{d}$. For the threshold defendant, the prosecutor captures the full gains of avoiding trial, $c_{p}+c_{d}$. 
Example: Again, suppose that $\theta(\pi, \alpha)=\pi \alpha$, with $\pi \subseteq(0,1)$ and $\alpha \subseteq(0,1)$. The optimal defendant threshold, $\alpha^{\star}$ and plea offer $s^{\star}$, are characterized by the first order condition:

$$
\frac{f\left[\alpha\left(s^{\star}\right)\right]}{1-F\left[\alpha\left(s^{\star}\right)\right]}=\frac{\pi x}{c_{p}+c_{d}}
$$

Proposition 2a: The optimal threshold $\alpha^{\star}$ is decreasing in the prosecutor's trial costs $c_{p}$, and defendant trial costs $c_{d}$, and increasing in the strength of the prosecutor's case $\pi$. Accordingly, the probability of acceptance of a plea offer increases with prosecutorial and defendant trial costs, and decreases with strength of prosecutor's case.

Proofs: An increase in $c_{p}$ and $c_{d}$ reduces the right-hand expression. Given the assumption that $\frac{f}{[1-F]}$ is strictly increasing in $\alpha, \alpha^{\star}$ must fall. The probability of plea acceptance, $1-F\left[\alpha^{\star}\right]$, increases. Because $\alpha_{s \pi}(s)<0$, an increase in $\pi$ increases the right-hand expression, requiring an increase in $\alpha^{\star}$, such that the probability of plea acceptance $1-F\left[\alpha^{\star}\right]$ falls.

Proposition 2b: The optimal plea sentence $s^{\star}$ is decreasing in the prosecutor's trial costs $c_{p}$, and increasing in the strength of the prosecutor's case $\pi$. The effect of increased defendant trial costs $c_{d}$ on the optimal plea sentence is ambiguous.

Proofs: The optimal plea offer to the threshold defendant is $s^{\star}=\theta\left(\pi, \alpha^{\star}\right) x+c_{d}$. An increase in $c_{p}$ reduces the optimal plea offer because it reduces $\alpha^{\star}$ (Proposition 2a). Intuitively, as trial costs increase, the prosecutor offers a lower plea sentence in order to conserve resources. An increase in $\pi$ increases the optimal plea offer because it directly increases $s^{\star}$ holding $\alpha^{\star}$ constant, but also increases $\alpha^{\star}$ (Proposition 2a). The effect of defendant trial costs $c_{d}$ on $s^{\star}$ is ambiguous. Holding the probability of acceptance constant, an increase in $c_{d}$ will increase $s^{\star}$. However, an increase in $c_{d}$ also reduces the acceptance threshold, $\alpha^{\star}$, reducing $s^{\star}$.

Given the prosecutor's plea offer $s^{\star}(\pi)$, the prosecutor in the first stage decides whether to bring charges given the strength of the case, $\pi$, and cost of initiating prosecution, $k$. The maximization problem is equivalent to the prosecutor selecting a cutoff $\pi^{\star}$ for which suspects with $\pi<\pi^{\star}$ are declined, and suspects with $\pi \geq \pi^{\star}$ are prosecuted. Formally, the prosecutor's decision rule results in a cutoff $\pi^{\star}$ that equates the expected benefit of prosecution with the expected cost of prosecution:

$$
k+c_{p} F\left[\alpha\left(s^{\star}\left(\pi^{\star}\right)\right]=\left\{1-F\left[\alpha\left(s^{\star}\left(\pi^{\star}\right)\right)\right]\right\} s^{\star}\left(\pi^{\star}\right)+x \int_{\underline{\alpha}}^{\alpha\left(s^{\star}\left(\pi^{\star}\right)\right)} \theta\left(\pi^{\star}, \alpha\right) f(\alpha) d \alpha\right.
$$

The prosecutor's expected costs of prosecuting a case include $k$ associated with initiating prosecution, and $c_{p}$ associated with going to trial with probability $F\left[\alpha\left(s^{\star}\left(\pi^{\star}\right)\right)\right]$. The prosecutor's expected benefits of prosecution include obtaining an accepted plea of $s^{\star}\left(\pi^{\star}\right)$ with probability 
$1-F\left[\alpha\left(s^{\star}\left(\pi^{\star}\right)\right)\right]$, and an expected sentence of $x \int_{\underline{\alpha}}^{\alpha\left(s^{\star}\left(\pi^{\star}\right)\right)} \theta\left(\pi^{\star}, \alpha\right) f(\alpha) d \alpha$ if the defendant rejects the plea offer and goes to trial.

Proposition 3: An increase in the costs of prosecution $k$ results in a higher threshold for prosecution $\pi^{\star}$.

Proofs: Because $s^{\star}$ is increasing in $\pi$ (Proposition 2b), and $\theta$ is increasing in $\pi$, the expected benefit of prosecution is increasing in the strength of the prosecutor's case. Accordingly, if there is an increase in the costs of prosecution $k$, the equilibrium cutoff for prosecution $\pi^{\star}$ increases. Intuitively, the prosecutor drops cases characterized by relatively weak evidence. ${ }^{29}$ An increase in prosecution costs shifts the prosecution threshold to the right, from $\pi^{\star}$ to $\pi^{\star \star}$, effectively truncating the distribution of cases that proceed.

The equilibrium is characterized by equations (1), (2), and (3). The equilibrium probability of dismissal is:

$$
G\left[\pi^{\star}\right]
$$

Conditional on prosecution, the equilibrium probability of a defendant accepting a guilty plea is:

$$
\int_{\pi^{\star}}^{\bar{\pi}} 1-F\left[\alpha\left(s^{\star}(\pi)\right)\right] g(\pi) d \pi
$$

and the equilibrium probability of conviction is:

$$
\int_{\pi^{\star}}^{\bar{\pi}}\left\{1-F\left[\alpha\left(s^{\star}(\pi)\right)\right]+\int_{\underline{\alpha}}^{\alpha\left(s^{\star}(\pi)\right)} \theta(\pi, \alpha) f(\alpha) d \alpha\right\} g(\pi) d \pi
$$

with the expected sentence in equilibrium:

$$
\int_{\pi^{\star}}^{\bar{\pi}}\left\{\left\{1-F\left[\alpha\left(s^{\star}(\pi)\right)\right]\right\} s^{\star}(\pi)+x \int_{\underline{\alpha}}^{\alpha\left(s^{\star}(\pi)\right)} \theta(\pi, \alpha) f(\alpha) d \alpha\right\} g(\pi) d \pi
$$

Comparative Statics of Increase in Resource Constraints

Given these equilibrium conditions, one can derive predictions of how changes in resources affect screening and plea bargaining behavior. The impact of judicial vacancies can be categorized into two main effects: a selection effect and a treatment effect.

\footnotetext{
${ }^{29}$ To the extent that weak evidence is correlated with the innocence of a defendant, the prosecutor is dropping cases against defendants with a higher likelihood of innocence.
} 
Selection Effect: First, judicial vacancies increase the costs of prosecution, $k$. Higher costs come in the form of constraints imposed by speedy trial requirements, with speedy trial violations leading to a dismissal of the case by the judge. Short of a speedy trial violation, prosecutors may also face costs associated with case delay, such as evidence becoming stale. Additionally, prosecutors may face reputational costs within the court from burdening judges with high caseloads. Because of higher costs of prosecution, prosecutors pursue those cases that have higher expected sanctions, dropping cases with weaker or more contestable evidence (Proposition 3).

Defendants who are selectively prosecuted are those for whom the prosecutor has stronger evidence. Accordingly, the average plea offer is less favorable (Proposition $2 b$ ), and the average probability of guilty pleas is lower (Proposition 2a) because of the selection effect.

Treatment Effect: Conditional on being prosecuted, how do judicial vacancies affect equilibrium outcomes? Prosecutorial trial costs, $c_{p}$, also increase in response to judicial vacancies because of speedy trial requirements, and because delay in going to trial can mean the loss of witnesses and their recollections of the events. If prosecutors' trial costs increase, the resulting plea offer is more favorable, increasing the likelihood of acceptance (Proposition $2 \mathrm{a}$ and $2 \mathrm{~b}$ ) - the treatment effect. On the other hand, if the impact of judicial vacancies on $c_{p}$ is negligible, the selection effect dominates, and the average plea offer is less favorable, with a corresponding lower rate of guilty pleas.

If judicial vacancies create longer delays to trial, a defendant's costs of going to trial $c_{d}$ may decrease. If defendant trial costs decrease, the likelihood of acceptance of a plea offer is also lower. Note this is more likely true for defendants who make bail. Defendants who are not granted bail may be more likely to plead guilty to avoid lengthy pre-trial detentions.

Overall, if prosecution costs increase, the model predicts an increase in case dismissals, but yields ambiguous effects on the aggregate rate of plea bargaining acceptances, and plea offer deals. This ambiguity stems from the opposing predictions from the selection and treatment effects. 


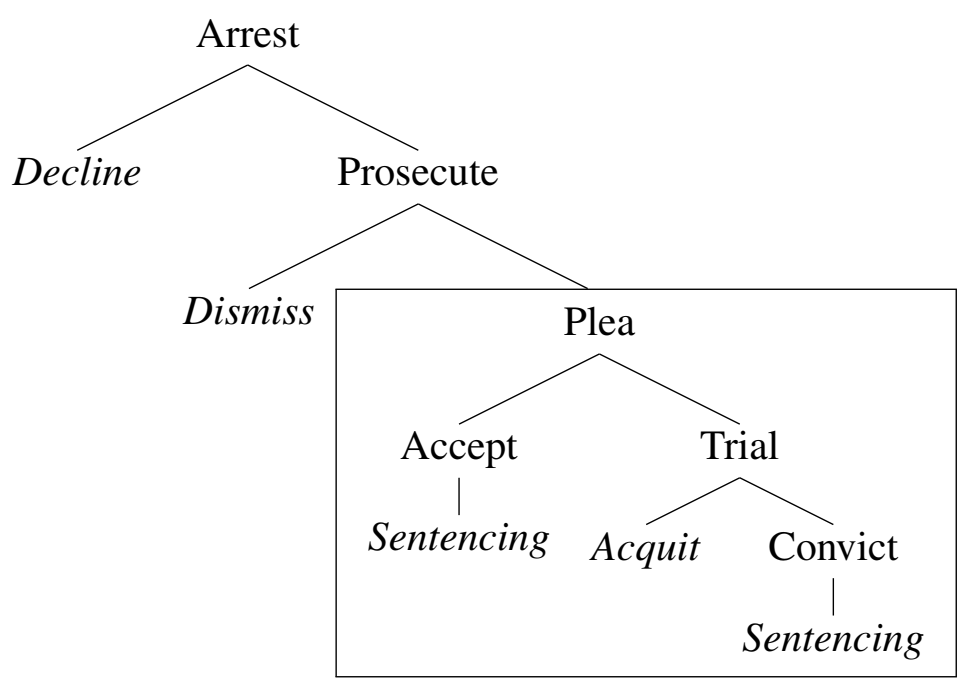

Appendix Figure 1 